\title{
Customer engagement in social media: a framework and meta-analysis
}

\author{
Fernando de Oliveira Santini \\ Universidade do Vale do Rio dos Sinos (UNISINOS) \\ Wagner Junior Ladeira \\ Universidade do Vale do Rio dos Sinos (UNISINOS) \\ Diego Costa Pinto(*) \\ NOVA Information Management School, Universidade NOVA de Lisboa \\ Márcia Maurer Herter \\ Universidade Europeia \\ Claudio Hoffmann Sampaio \\ Pontifícia Universidade Católica do Rio Grande do Sul (PUC/RS) \\ Barry Babin \\ University of Mississipi
}

This is the author accepted manuscript of the following article published by Springer:

Santini, F. D. O., Ladeira, W. J., Pinto, D. C., Herter, M. M., Sampaio, C. H., \& Babin, B. J. (2020). Customer engagement in social media: a framework and meta-analysis. Journal Of The Academy Of Marketing Science. [Advanced online publication on 27 May 2020]. Doi: https://doi.org/10.1007/s11747-020-00731-5

\section{c) (i) (5)}

This work is licensed under a Creative Commons Attribution-NonCommercial 4.0 International License. 


\section{Customer Engagement in Social Media: A Framework and Meta- Analysis}

\section{Fernando de Oliveira Santini}

E-mail: santiniconsultores@gmail.com

Address: Av. Unisinos, 950, São Leopoldo / RS / Brazil, Zip Code: 93022-000

Phone: $+55-51-3591-1122$

Academic affiliations: Universidade do Vale do Rio dos Sinos (UNISINOS)

\section{Wagner Junior Ladeira}

E-mail: wladeira@unisinos.br

Address: Av. Unisinos, 950, São Leopoldo / RS / Brazil, Zip Code: 93022-000

Phone: +55-51-3591-1122

Academic affiliations: Universidade do Vale do Rio dos Sinos (UNISINOS)

\section{Diego Costa Pinto (*)}

E-mail: dpinto@novaims.unl.pt

Address: Campus de Campolide, Lisboa, Portugal, Zip Code: 1070-312

Phone: $+\underline{351213828610}$

Academic affiliations: NOVA Information Management School, Universidade NOVA de Lisboa

\section{Márcia Maurer Herter}

E-mail: marcia.herter@universidadeeuropeia.pt

Address: Quinta do Bom Nome, Estr. Correia 53, Lisboa, Portugal, Zip Code: 1500-210

Phone: $+\underline{351210309900}$

Academic affiliations: Universidade Europeia

\section{Claudio Hoffmann Sampaio}

E-mail: csampaio@pucrs.br

Address: Av. Ipiranga, 6681, Porto Alegre / RS / Brazil, Zip Code: 90619-900

Phone: $+55-51-3320-3500$

Academic affiliations: Pontifícia Universidade Católica do Rio Grande do Sul (PUC/RS)

\section{Barry Babin}

E-mail: bjbabin@olemiss.edu

Address: P.O. Box 1848, University, MS 38677 USA

Phone: 318.257 .2000

Academic affiliations: University of Mississipi

*Corresponding author. 


\title{
Customer Engagement in Social Media: A Framework and Meta-Analysis
}

\begin{abstract}
This research examines customer engagement in social media (CESM) using a meta-analytic model of 814 effect sizes across 97 studies involving 161,059 respondents. Findings reveal that customer engagement is driven by satisfaction, positive emotions, and trust, but not by commitment. Satisfaction is a stronger predictor of customer engagement in high (vs. low) convenience, B2B (vs. B2C), and Twitter (vs. Facebook and Blogs). Twitter appears twice as likely as other social media platforms to improve customer engagement via satisfaction and positive emotions. Customer engagement is also found to have substantial value for companies, directly impacting firm performance, behavioral intention, and word-of-mouth. Moreover, hedonic consumption yields nearly three times stronger customer engagement to firm performance effects vis-à-vis utilitarian consumption. However, contrary to conventional managerial wisdom, wordof-mouth does not improve firm performance nor does it mediate customer engagement effects on firm performance. Contributions to customer engagement theory, including an embellishment of the customer engagement mechanics definition, and practical implications for managers are discussed.
\end{abstract}

Keywords: customer engagement, firm performance, meta-analysis, online consumer behavior, social media 


\section{Introduction}

Marketing practitioners and scholars recognize that customer engagement in social media is an important marketing outcome (Hollebeek et al. 2014; Rietveld et al. 2020; Simon and Tossan 2018; Wang and Kim 2017). Nine out of ten medium and large businesses spend a minimum of $11 \%$ of their total marketing budget on social media platforms like Twitter, Instagram, Facebook, Pinterest, and LinkedIn, in an effort to encourage greater customer engagement (Forbes 2018a; Harvard Business Review 2018). U.S. investment in digital marketing efforts is expected to grow from \$108 in 2018 to over $\$ 150$ billion in 2020, reflecting the continued relevance of digital platforms including social media (Forbes 2019). Globally, the potential return of social media engagement for firms is even bigger: $49 \%$ of the world's population uses social media, representing about 3.8 billion potentially engaged customers in 2020 (Forbes 2020a).

However, companies encounter challenges in converting media investments into meaningful customer engagement. Although companies invest about $\$ 84$ billion in social media marketing (Zenith Media 2020), the CMO survey reveals a lack of net positive returns: only 30\% of CMOs are confident of social media's positive impacts on firm performance (Forbes 2020b). Indeed, $40 \%$ of consumers follow their "favorite" brands on social media, but only about $25 \%$ of followers actually purchase brands they follow (Forbes 2018b).

The marketing literature also provides inconsistent findings regarding the effects of customer engagement on social media (e.g., Hollebeek et al. 2014; Hunter and Schmidt 2004). Some studies suggest that customer engagement strongly relates to word-of-mouth (WOM) $(r=$ .50; Halaszovich and Nel 2017), while others find only a weak relationship $(r=.14$; Badrinarayanan et al. 2015). Still, other studies find neutral, positive, or even negative 
relationships between customer engagement and firm performance (Beckers et al. 2018; Cheung et al. 2015; Wong and Merrilees 2015). These conflicting results suggest that customer engagement effects vary and that the extant literature and managerial guidelines are potentially unreliable.

Consequently, in this study, we synthesize the customer engagement literature's multiple perspectives and measures and present a framework for studying customer engagement in social media (CESM framework). In the framework, we elaborate on customer engagement's contributions to marketing firms (Kumar et al. 2010; Kumar 2013; Pansari and Kumar 2017), using a meta-analytic structural model involving 814 effect sizes, across 97 studies, involving 161,059 respondents. The meta-analysis addresses theoretical and practical gaps in the literature by exploring the antecedents, consequences, and potential moderators of customer engagement in social media. Thus, beyond the review, the paper makes at least three contributions to customer engagement theory and practice (e.g., Beckers et al. 2018; Kumar et al. 2019; Pansari and Kumar 2017): (1) the paper presents a theoretically-grounded framework of customer engagement in social media, (2) it provides a comprehensive empirical analysis of customer engagement drivers and consequences, and (3) it suggests under which conditions customer engagement in social media is more or less effective. The findings help resolve inconsistencies in previous work by testing whether customer engagement is driven by satisfaction, positive emotions, trust, and commitment; and by exploring boundary conditions to customer engagement effects.

This paper is organized as follows. First, we review the development of the customer engagement field and its four major perspectives (intrinsic motivations, psychological mind states, customer activities, or contributions to firms). Second, we describe the CESM conceptual 
framework, including its main drivers and consequences, while recognizing that potential moderators may set boundaries for effects. Third, we detail our methodological procedures to test the CESM framework. And finally, we discuss the meta-analytical findings and provide key theoretical and practical insights concerning the customer engagement concept.

\section{Development of the customer engagement field}

Extant research offers numerous marketing strategies and customer management policies aimed at potentially strengthening customer engagement and firm value (e.g., Brodie et al. 2011; Harmeling et al. 2017; Higgins and Scholer 2009; Kumar 2013; Kumar and Pansari 2015; Van Doorn et al. 2010; Venkatesan 2017; Verhoef et al. 2002, 2010). One point that is clear across the literature is that firms devote resources toward developing customer engagement beyond mere discrete firm-customer transactions (Pansari and Kumar 2017).

In the 1990 s, marketing research shifted attention toward share-of-wallet, purchase frequency, and subsequent customer lifetime value of a customer to the firm (Pansari and Kumar 2017). Relationship marketing philosophies emerged and looked at trust and/or commitment as bases for establishing positive long-term customer relationships (Moorman et al. 1993; Morgan and Hunt 1994).

As the technology evolved, consumers increasingly gained access to digital and social media platforms as a means of expressing opinions and interacting with companies. Many firms shifted promotional resources from traditional media and began using digital platforms to directly interact with customers (Paruthi and Kaur 2017). For example, Coca-Cola, Starbucks, Dove, Microsoft, Dell, and Nike began using social media as a primary marketing tool (Baldus et 
al. 2015; Paruthi and Kaur 2017). Consequently, in the early 2000s, the relationship marketing literature began studying customer engagement (Kumar 2013).

Early customer engagement investigations and conceptualizations could not address recent technological innovations that continue to open new possibilities for customer-firm interaction (Paruthi and Kaur 2017). However, over the past two decades, as digital platforms evolved, firms' marketing strategies led to investments aimed at building unique brand experiences through interactive multimedia environments (Paruthi and Kaur 2017). Marketing managers started to use social media to identify highly engaged customers for specialized marketing efforts (Kumar et al. 2010) and to ensure that they remain emotionally, profitably, and sustainably connected (Paruthi and Kaur 2017).

\section{Perspectives on customer engagement}

Although customer engagement studies have increasing theoretical and managerial relevance, researchers lack a unified basis for investigating customer engagement in social media (Paruthi and Kaur 2017). Customer engagement may be a relatively nascent concept in comparison with customer satisfaction or loyalty, but more than twenty studies offer relevant perspectives regarding customer engagement in social media (e.g., Baldus et al. 2015; Hollebeek et al. 2014). Contrasting perspectives provide bases for at least eight scales measuring customer engagement in social media (Algesheimer et al. 2005; Baldus et al. 2015; Calder et al. 2009; Hollebeek et al. 2014; Hopp and Gallicano 2016; Obilo et al., 2020; Paruthi and Kaur 2017; Sprott et al. 2009). Appendix A summarizes the literature's perspectives on customer engagement by presenting the various definitions, contexts, and scale dimensions. 
The various conceptualizations and measurements of customer engagement can be divided into four main perspectives (Harmeling et al. 2017): intrinsic motivations, psychological mind states, customer activities, or contributions to firms. Customer engagement, as intrinsic motivation, implies that consumers are driven by desires to interact and cooperate with “community members" (Algesheimer et al. 2005, p. 21) or participate in "an online brand community" (Baldus et al. 2015, p. 979). Nonetheless, the intrinsic motivation concept fails to consider that social media users may be extrinsically motivated to acquire likes, comments, and recognition.

Customer engagement as a psychological mind state indicates that consumers "include important brands as part of their self-concept" (Sprott et al. 2009, p. 92) or feel "internal emotion" from brand attachments (Paruthi and Kaur 2017, p. 128). Although consumers may engage with brands relevant to their self-concept and feel internal emotions, from a marketing success standpoint, consumers must also perform brand-enhancing actions. Thus, customer engagement has been conceptualized as an activity, such as a "collection of experiences" (Calder et al. 2009, p. 322), "intentions to give online recommendations" (Hopp and Gallicano 2016, p. 129), or to include "activities related to specific consumer/brand interactions" (Hollebeek et al. 2014, p. 154). Defining customer engagement as customer activities fits the social media context, but it does not necessarily imply that customer engagement actions add value to the firm.

Pansari and Kumar (2017, p. 295) define customer engagement as "the mechanics of a customer's value addition to the firm, either through direct or/and indirect contribution." Thus, in a "contributions to firms" view, customer engagement is thought to improve firm performance by encouraging both direct and indirect contributions (Kumar et al. 2010; Kumar 2013; Pansari and Kumar 2017). Perhaps the most intriguing aspect of the definition deals with the 
"mechanics." While some elements of the mechanics may seem clear (purchase as a direct contribution and WOM as an indirect contribution), the notion of mechanics suggest that customer engagement cannot be looked at as an isolated construct. Rather, a customer engagement construct is relevant only as part of a process leveraging firm resources into success.

We argue that customer engagement as intrinsic motivation or as a psychological state alone cannot directly add value to the firm performance. Customer activities are required, including transactions, but also perhaps via behaviors that elaborate on brand-related social media content as a way of acting like advertising.

\section{Framework of customer engagement in social media (CESM)}

The marketing literature considers customer engagement as having potential predictive power regarding consumer outcomes and firm performance (Bijmolt et al. 2010; Dutot and Moscovi 2016; Kumar 2013). Pansari and Kumar (2017) posit that customer engagement occurs when customers form satisfying relationships based on trust, commitment, and emotional bonding. We elaborate on these key theoretical components in developing a three-stage CESM framework. The three stages move from: (1) relationship formation, in which trust and commitment impact satisfaction and positive emotions, (2) customer engagement resulting from satisfaction, positive emotions, trust, and commitment, and (3) customer engagement contributes directly to firm performance and indirectly as mediated by behavioral intention and WOM (Figure 1). The literature also acknowledges that customers' contribution to the firm might generate feedback effects on relationship formation and customer engagement. However, whereas feedback effects are theoretically important, the lack of empirical research presenting 
feedback effects precludes a meaningful investigation via meta-analysis. Feedback effects are further discussed in the limitations and future research section.

Insert Figure 1 about here

\section{Relationship formation}

Customer engagement is based on trust and commitment that then generate satisfaction and positive emotions (Pansari and Kumar 2017).

Trust Trust indicates a willingness to rely on exchange partners (Moorman et al. 1993). Highly trusting customers are expected to be more engaged (Gustafsson et al. 2005), especially in social media (Tsai et al. 2012). For example, online community participants form a sense of group belonging, which then increases their trust in the community (Hollebeek 2011). Marketing studies, including those in online community contexts, tend to directly associate trust with satisfaction and positive emotions (e.g., Brodie et al. 2013; Geyskens et al. 1999; Zboja and Voorhees 2006). Thus, we expect that trust positively affects satisfaction and positive emotions.

Commitment Commitment indicates customers' willingness to stay in long-term relationships (Van Lange et al. 1997), to be engaged in brand-community interactions, and to advocate for brands (Brodie et al. 2013; Mollen and Wilson 2010; Park and MacInnis 2006). Such interactions yield both cognitive satisfaction and positive affect (Mollen and Wilson 2010), forming a basis 
for commitment and emotional bonding (Bowden 2009a; Brodie et al. 2013). Thus, we propose that commitment positively affects positive emotions and satisfaction.

\section{Customer engagement}

When consumers enjoy emotionally bonding relationships with firms, they become engaged (Pansari and Kumar 2017). We posit that satisfaction and positive emotions are the two main drivers creating customer engagement in social media and mediate the relationships between trust-CE and commitment-CE. These activities could be related to CE, such as customers' experiences (Calder et al. 2009), brand interactions (Hollebeek et al. 2014), and online consumption and recommendations (Hopp and Gallicano 2016), generating value to firms (Pansari and Kumar 2017).

Satisfaction Positive cognitive and affective evaluations of consumption outcomes lead to satisfaction (Mano and Oliver 1993). Satisfied customers tend to show the enthusiasm and pleasure typical of high customer engagement (Gummerus et al. 2012), to indicate the satisfaction and trust underlying customer engagement (Brodie et al. 2013), and to promote firms (Pansari and Kumar 2017), especially in social media contexts. Thus, we expect that satisfaction positively affects customer engagement.

\footnotetext{
Positive emotions Consumer emotions represent a state of mind arising from cognitive and affective appraisals of consumption activities (Bagozzi et al. 1999). Positive emotions include agreeableness and feelings of enthusiasm, freedom of expression, and create positive outcome expectations (Pansari and Kumar 2017). We propose that positive emotional appraisals about
} 
consumption experiences will trigger mind-states that determine behavior, such as hedonic value and customer engagement (Bagozzi et al. 1999; Pansari and Kumar 2017). Therefore, the theory suggests that positive emotions positively affect customer engagement.

Mediation effects The recent customer engagement theory explains that when a relationship is formed based on trust and commitment, satisfaction and positive emotions will stimulate customer engagement (Pansari and Kumar 2017). We propose that the nature of the interaction determines the extent of emotional attachment and satisfaction; in the case of social media, commitment and trust create temporal stability in the attachment-behavior relationship (Park and MacInnis 2006) and cause positive emotions and satisfaction (Mollen and Wilson 2010; Thomson et al. 2005). We argue that trustful and committed relationships lead customers and firms to enjoy the satisfaction and emotional bonding. Consequently, we expect that satisfaction and positive emotions mediate the effects of trust-CE and commitment-CE.

\section{Customer engagement contributions}

Engaged customers can contribute to firms' well-being directly through patronage behavior and indirectly through positive WOM (Kumar et al. 2010). We propose that behavioral intention and WOM follow customer engagement and mediate the relationship between customer engagement and firm performance.

Behavioral intention Customers' behavioral intentions imply their willingness to continue interacting in ways that will benefit the firm and to seek out other brand-related experiences (Babin et al. 1994). Customer engagement and perceived personal relevance then motivate 
behavioral intention and behavior, including purchases (Algesheimer et al. 2005), that drive firm performance. Thus, we expect that customer engagement positively affects customer behavioral intention, which ultimately may improve firm performance.

WOM WOM refers to the spontaneous propagation of positive and/or negative information (Hennig-Thurau et al. 2004), based on desires to establish and maintain social relationships (Chu and Kim 2011). Engaged customers tend to use social media and electronic WOM to share positive information and experiences (Chu and Kim 2011), which generates value for companies (See-To and Ho 2014; Vivek et al. 2012). Thus, we expect customer engagement to be positively and directly related to positive WOM, which ultimately may influence the firm's performance.

Firm performance Social media channels encourage users to increase the number of followers and potential customers (Ashley and Tuten 2015). Marketing professionals are particularly hopeful that customer engagement has positive implications for sales growth and financial performance (Brodie et al. 2011; Dessart et al. 2015). Some researchers suggest that social media engagement is a new metric for gauging direct or correlative effects on firm performance (Ashley and Tuten 2015; Brodie et al. 2011; Vivek et al. 2012; Wong and Merrilees 2015). However, customer engagement is found to have neutral, moderate, or even negative relationships with firm performance (Cheung et al. 2015; Wong and Merrilees 2015); the nature of the relationship perhaps depending on conditions such as advertising intensity and corporate reputation (Beckers et al. 2018). Thus, we aim to reconcile past inconclusive findings by examining the relationship between customer engagement and firm performance. 
Mediation of customer contributions Engaged customers are motivated to make direct and indirect contributions such as purchasing products, spreading positive WOM, conversing on social media, and providing feedback and suggestions (Kumar et al. 2010; Pansari and Kumar 2017). Based on the literature, we argue that behavioral intentions mediate the relationship between customer engagement and firm performance by promoting financial performance and sales growth (Morgan and Rego 2006).

The literature also suggests that WOM positively impacts firm reputation and performance (Aggarwal et al. 2012). Indeed, compared with traditional advertising, WOM produces relatively more positive performance outcomes (Trusov et al. 2009) and adds more to firm value (Villanueva et al. 2008). Perhaps the added value is because WOM both attracts new consumers and retains long-term consumers (Van Doorn et al. 2010). Therefore, we tested behavioral intention and WOM as mediators of customer engagement on firm performance.

\section{Moderators of customer engagement}

Studies of customer engagement in social media tend to focus on information and communication technologies (Brodie et al. 2013), customer-brand relationships (Hollebeek et al. 2014), dynamic interactive environments (Brodie et al. 2011), and the expression of diverse personality traits and behavioral inclinations (Claffey and Brady 2017). The studies exhibit widely fluctuating effect sizes, suggesting that moderators might be needed to better understand the way customer engagement works (Rosenblad 2009). Consequently, we explore potential customer engagement moderators that might reduce heterogeneity in observed effects.

Drawing on customer engagement theory (Pansari and Kumar 2017), we explore contextual moderators of customer engagement, such as convenience, type of firm, type of 
industry, and product involvement. We also explore the type of social media (Beckers et al. 2018) and customer-value type (Babin et al. 1994) as potential contextual moderators for customer engagement. In typical meta-analytic fashion (Grewal et al. 2018; Lipsey and Wilson 2001), we also explore study characteristics used as potential moderators. Table 1 presents the definition and coding procedure.

Insert Table 1 about here

Convenience Convenience indicates how much time and effort customers must expend to purchase goods or services (Brown 1990). Although consumers, in general, tend to perceive that online environments are more convenient because of the ease of accessing information, convenience characteristics are related to time, opportunity, and energy customers expend for goods or services (Pansari and Kumar 2017). We thus explore how convenience consumption contexts (i.e., related to customers' time and effort towards a type of product or service) moderates customer engagement effects.

Type of firm The B2B and B2C firm distinction is thought to influence purchase decision processes (Pansari and Kumar 2017). In B2B contexts, decision-making is thought to be more complex because the process involves multiple agents within the company, each with their own agenda (Pansari and Kumar 2017). We compare B2B and B2C effects to explore whether firm type moderates customer engagement effects. 
Type of industry Services contexts have intangible characteristics and tend to be more heterogeneous than manufacturing contexts (Zeithaml et al. 1985). Consequently, service firms must provide customers with more details to form customer relationships and customer engagement (Hollebeek et al. 2016; Pansari and Kumar 2017). We explore whether industry type (service vs. manufacturing) moderates customer engagement effects.

Product involvement Highly involved consumers perceive brands and their goods or services as personally relevant to their needs, values, and interests (Zaichkowsky 1985). Consumers tend to be less involved with frequently-purchased products and experience greater motivation, arousal, and cognitive elaborations with infrequently-purchased products like durable goods (Mano and Oliver 1993; Pansari and Kumar 2017). We explore whether product involvement (high vs. low) moderates customer engagement effects.

Product value Utilitarian and hedonic value results from different customer experiences (Babin et al. 1994; Hagtvedt and Patrick 2009). Functional benefits create utilitarian value but typically are associated with low-arousal emotions. In contrast, hedonic value is associated with experience, pleasure, fun, and adventure, and can involve high-arousal emotions (Hirschman and Holbrook 1982; Smith and Colgate 2007); the stronger emotions creating potential for stronger customer-brand relationships and stronger consumer-to-consumer connections (Bowden 2009b). Thus, we explore whether a hedonic and utilitarian value distinction moderates customer engagement effects. 
Type of social media Social media enables real-time interactions for increasing customer-brand interactions and relationships (Labrecque 2014). Our meta-analysis review revealed that previous studies focus on three main types of social media: blogs, Facebook, and Twitter. When social media channels such as Facebook and Twitter support customer engagement initiatives, they tend to create greater value and customer engagement relative to blogs (Beckers et al. 2018). But, distinctions between the channels remain theoretically undeveloped. Rather than predict how the type of social media will influence customer engagement, we explore whether the type of social media moderates customer engagement effects.

Study characteristics In addition to contextual moderators, we analyzed study-related variables. We investigated sample sizes, publication types, and study settings. We allocated sample sizes as small or large based on the median cut-off point (Hedges and Olkin 1985), distinguished study settings between surveys and experiments (Eisend 2017), and publication types between published and unpublished manuscripts (Lipsey and Wilson 2001; Rosenthal 1979).

\section{Methodological procedures}

Our methodological approach follows well-grounded procedural recommendations for meta-analytic approaches including preferred reporting items for systematic reviews and metaanalyses (PRISMA) (Moher et al. 2009), coding scheme (Rust and Cooil 1994), data extraction and meta-analytic calculations (Babić-Rosario et al. 2016; Kim and Peterson 2017), metaanalytic structural equation modeling (MASEM) (e.g., Cheung and Chan 2005), and hierarchical linear meta-analysis (HiLMA) (Geyskens et al. 2009). 


\section{Study retrieval}

Search procedure To identify published and unpublished studies (Rosenthal and DiMatteo 2001) that reported empirical results on or before May 1, 2019, we first searched Google scholar using the keywords/terms customer engagement, consumer engagement, engagement, social engagement, brand engagement, and online engagement in the document title and/or summary fields. Second, we manually checked the studies identified through the electronic search to uncover additional studies that developed scales to measure social media engagement. Third, we used the same keywords to search eight electronic databases: JSTOR, Emerald, PsycINFO, Taylor \& Francis, Elsevier, Science Direct, SCOPUS, Scielo, and EBSCO. Fourth, we manually searched for the full text of papers presented at leading congresses across the marketing and information systems academies: The Academy of Marketing Science Conferences (Annual and World Marketing Congress), the Association for Consumer Research, the European Marketing Academy, American Marketing Association, Global Marketing Conference, INFORMS, and European Conference on Information Systems. Fifth, we checked the ProQuest Dissertations \& Theses Global platform to find unpublished studies as an opening for addressing the file-drawer problem arising from academic journals bias to publish studies that report statistically significant effects (Rosenthal 1979).

Inclusion criteria and final sample We identified 983 articles/papers using PRISMA (Moher et al. 2009). We included only studies that (1) examined customer engagement in social media and (2) presented sufficient statistical information for use in meta-analysis. The first condition eliminated 609 studies. We also exclude 277 articles that report only qualitative data. The final sample includes 814 effect sizes from 97 studies published over an 11-year span, representing 92 
independent samples involving a total of 161,059 respondents. The Web Appendix presents a list of the primary studies included in the meta-analysis.

Coding and extraction procedure The coding scheme for contextual and study-related moderators followed the procedure suggested by Rust and Cooil (1994). After discussing the coding classification criteria, three research assistants individually coded the effect sizes, compared their codification, and obtained an overall agreement index of $89.1 \%$. The agreement index and the total number of observed effect sizes for each moderator was: convenience $(82.5 \%$, $N=114)$, type of firm $(88.6 \%, N=44)$, type of industry $(100 \%, N=151)$, product involvement $(81.9 \%, N=193)$, product value $(81.6 \%, N=141)$, and type of social media $(100 \%, N=130)$. A fourth judge resolved disagreements. The procedure used for data extraction followed previous research in meta-analyses (Babić-Rosario et al. 2016; Kim and Peterson 2017) and each moderator was treated as a single class variable with different categories (e.g., type of social media had three levels: Blog, Facebook, Twitter). Only a portion of studies could be coded for each moderating characteristic (see Table 1 for coding details).

\section{Meta-analytic calculations}

Effect size calculation To analyze the data, we followed procedures suggested in previous metaanalyses research (Babić-Rosario et al. 2016; Hedges and Olkin 1985; Kim and Peterson 2017). Customer engagement correlations were extracted directly from articles (a Web Appendix lists all articles). When an article employed a multidimensional CE measure, the multiple correlations for an effect were aggregated into a single correlation for a particular effect. Pearson's correlation coefficient (r) is, thus, the common effect size for the main variables in the model and 
was by far the most commonly available metric in the set of articles employed. However, metaanalyses routinely perform statistical conversion procedures to provide results in a common effect metric (e.g., Kim and Peterson 2017; Santini et al. 2018). When studies failed to report correlations, we converted other statistics such as mean differences, t-tests, or F-ratios to correlations (see Hunter and Schmidt 2004; Peterson and Brown 2005). Once we assembled the relevant effect sizes, we corrected them in relation to the reliability of the scales and sample size (Hedges and Olkin 1985). Table 2 presents the resulting correlation matrix.

Insert Table 2 about here

MASEM and moderation analysis We employed MASEM to test the CESM framework, which performs meta-analytic analysis of covariance structure using standard structural equation modeling estimation (Cheung 2015; Cheung and Chan 2005; Hauk et al. 2018). R packages metaSEM (Cheung 2015) and OpenMx 2.0 (Neale et al. 2016) implemented the required analyses. The moderation analysis employed HiLMA, a multivariate regression-based approach (Geyskens et al. 2009) widely used in meta-analytic research (e.g., Babić-Rosario et al. 2016). In this case, the metaphor R package was employed (Viechtbauer 2010).

\section{Meta-analytic results}

We placed the necessary constraints on the summary correlation matrix to represent the CESM framework. MASEM results provide indices indicating reasonably good model fit $\left(\chi^{2}=\right.$ 
$110.68, d f=14, C F I=.974$, and RMSEA = .01) (Hair, Babin, and Krey 2017). Thus, we next interpret the resulting maximum likelihood (ML) path coefficient estimates. Figure 2 summarizes MASEM parameter estimates from the proposed framework.

Insert Figure 2 about here

\section{Relationship formation $\rightarrow$ Customer engagement}

First, we examine the trust and commitment direct effects on satisfaction and positive emotions. Results suggest that trust $(\beta=.440 ; p<.01)$ and commitment $(\beta=.179 ; p<.05)$ positively and significantly impact satisfaction. In contrast, the direct effects of both trust $(\beta=$ $.216 ; n s)$ and commitment $(\beta=.160 ; n s)$ on positive emotions are insignificant. Table 3 summarizes MASEM results for the CESM framework.

Insert Table 3 about here

Second, the CESM model predicts that satisfaction and positive emotions impact customer engagement directly. Results suggest that both satisfaction $(\beta=.327 ; p<.001)$ and positive emotions $(\beta=.357 ; p<.001)$ positively and significantly impacts customer 
engagement. In addition, results indicate that trust significantly and directly influences customer engagement $(\beta=.352 ; p<.001)$ while commitment's direct effect on customer engagement is not significant $(\beta=.074 ; n s)$.

Third, we examined satisfaction and positive emotions potential to mediate the trust-CE and commitment-CE paths. We tested the mediation effects following Jak's (2015) and Cheung's (2015) procedure that provides bias-corrected maximum likelihood-based confidence intervals to test indirect effects on customer engagement.

The CESM model posits that both trust and commitment impact customer engagement indirectly through satisfaction and positive emotions. The indirect effect of trust on customer engagement through satisfaction is statistically significant $(\beta=.144 ; p<.05)$, as is the indirect effect of commitment on customer engagement mediated by satisfaction $(\beta=.059 ; p<.05)$. The mediation effects of satisfaction on the trust-CE path (trust $\rightarrow$ satisfaction $\rightarrow \mathrm{CE}$ ) is qualified, however, by the simultaneous presence of a direct and nontrivial effect of trust on customer engagement $(\beta=.35 ; p<.001)$. Indeed, the direct effect is considerably stronger than the indirect effect. The mediation effect of satisfaction on the commitment-CE path (commitment $\rightarrow$ satisfaction $\rightarrow \mathrm{CE}$ ), although free of a simultaneous, significant, direct, commitment-CE path, is qualified by what could be considered a trivial effect size $(<.1)$ (Borenstein et al. 2019).

Positive emotions did not mediate the effects of trust on customer engagement $(\beta=.077$; $n s)$, nor commitment indirect effects $(\beta=.057 ; n s)$. These results do not support the proposed mediation effect of positive emotions on the trust-CE path (trust $\rightarrow$ positive emotions $\rightarrow$ customer engagement) and commitment-CE path (commitment $\rightarrow$ positive emotions $\rightarrow$ customer engagement). 


\section{Customer engagement $\rightarrow \mathrm{CE}$ contributions}

Next, we analyzed if and how customer engagement might contribute to behaviors and firm performance. Results first suggest that customer engagement positively and significantly affects behavioral intention $(\beta=.641 ; p<.001)$, WOM $(\beta=.555 ; p<.001)$, both with robust effect sizes, and customer engagement also positively influences firm performance $(\beta=.313 ; p$ $<.001)$. In addition, behavioral intention exhibits a direct, positive effect on firm performance $(\beta$ $=.378 ; p<.001)$, while, surprisingly, the WOM-performance path is not significant $(\beta=-.036$; $n s)$.

The CESM model further posits behavioral intention (direct contributions) and WOM (indirect contributions) as comprising the pathways between customer engagement and firm performance. The MASEM results suggest that behavioral intention mediates the relationship between customer engagement and firm performance, exhibiting a positive indirect effect $(\beta=$ $.243 ; p<.05)(\mathrm{CE} \rightarrow$ behavioral intention $\rightarrow$ firm performance). However, surprisingly, the results suggest that WOM does not mediate the path between customer engagement and firm performance as the indirect effect is not significant $(\beta=-.020 ; n s){ }^{1}$

\section{Moderation analysis: Exploring contextual characteristics}

We conducted a moderation analysis to explore the impact of contextual characteristics that may explain heterogeneity among the paths representing customer engagement's antecedents and consequences. First, we first consider the potential moderating effects of convenience, firm

\footnotetext{
${ }^{1}$ We did examine an alternative model allowing direct effects of trust and commitment on firm performance, behavioral intention and WOM. The chi-square difference between the CESM model and the alternative is 19.9 with $4 \mathrm{df}(p=.00052)$. The CFI suggests a slight improvement in fit to 0.98 versus 0.97 . The improvement in fit is due largely due to a positive, significant, and nontrivial trust-performance relationship. More importantly, the addition of the direct paths does not affect the parameter estimates to any large degree as the correlation between the CESM estimates and the alternative model is $r=0.922$. The parameter stability further provides evidence of a lack of bias due to interpretational confounding.
} 
type, industry type, product involvement, product value, and social media type using HiLMA. HiLMA, as a form of meta-regression (Grewal et al. 2018), treats the effect sizes as dependent variables and potential moderators as explanatory variables. Here, all moderator variables are dichotomized for convenience, with the exception of social media type (trichotomized). Table 4 shows results for the potential moderators of customer engagement in social media. The table includes the slope coefficients and the group effect sizes (correlations by group). In the text, we focus on the group differences as clearly illustrative of differences due to customer engagement context.

Insert Table 4 about here

Satisfaction $\rightarrow$ Customer engagement Results suggest that convenience, firm type, product involvement, product value, and social media type moderate the satisfaction-CE relationship. Results indicate that for high convenience, satisfaction has a stronger positive effect on customer engagement compared to low convenience $\left(r_{\text {high }}=.629 ; r_{\text {low }}=.235 ; p<.05\right)$. Thus, satisfaction more closely relates to customer engagement in convenience-consumption contexts. In addition, firm type moderates the satisfaction-CE path. For B2B firms, satisfaction yields approximately twice as big an effect on customer engagement compared to B2C firms $\left(r_{B 2 B}=.543 ; r_{B 2 C}=\right.$ $.250 ; p<.05)$. Results also suggest the moderating role of product involvement indicating that high rather than low product involvement enhances satisfaction-CE effects $\left(r\right.$ high $=.405 ; r_{\text {low }}=$ $.176 ; p<.05)$. Plus, results suggest that hedonic value, rather than utilitarian value contexts, is 
associated with a more positive satisfaction-CE relationship $(r$ hedonic $=.658 ; r$ utilitarian $=.241 ; p<$ $.001)$

Regarding social media type, results suggest that Twitter, in contrast with blogs or Facebook, yields much stronger positive satisfaction-CE $\left(r_{\text {twitter }}=.477 ; r_{\text {blog }}=.206 ; r_{\text {facebook }}=\right.$ $.199 ; p<.001)$ and positive emotions-CE relationships $\left(r_{\text {twitter }}=.840 ; r_{\text {blog }}=.336 ; r_{\text {facebook }}=\right.$ $.397 ; p<.05)$. Moderation results suggest that the identified predictors can better explain customer engagement in Twitter relative to other social media platforms. No other significant moderating effects are found for either the satisfaction-CE or positive emotions-CE path.

\section{Customer engagement and firm performance Customer engagement effects on firm} performance are significantly moderated by convenience, industry type, product involvement, and product value. In exploring contextual moderators on customer engagement contributions, we find that the effects of $\mathrm{CE}$ on firm performance are significantly lower in high versus low convenience contexts $\left(r_{\text {high }}=.211 ; r_{\text {low }}=.262 ; p<.001\right)$. For industry type as moderator, HiLMA indicates a stronger CE-firm performance relationship among manufacturing companies compared to service industries $\left(r_{\text {manufacturing }}=.333 ; r_{\text {service }}=.232 ; p<.001\right)$.

HiLMA analysis also suggests the moderating role of product involvement, indicating that, high-involvement contexts are associated with a CE-firm performance correlation three times stronger than low-involvement contexts $\left(r_{\text {high }}=.341 ; r_{\text {low }}=.107 ; p<.001\right)$. For product value type, customer engagement displays an almost three-times stronger effect on firm performance for hedonic rather than utilitarian consumption contexts $\left(r_{\text {hedonic }}=.307 ; r_{\text {utilitarian }}=\right.$ $.107 ; p<.001)$. No other moderating effects are found for the CE-firm performance path. In addition, no moderating effects are found for either CE-behavioral intention or CE-WOM paths. 


\section{Moderation Analysis: exploring study characteristics}

Additionally, in keeping with meta-analytic tradition (Grewal et al. 2018), we explored moderation due to study characteristics. HiLMA was used to explore the moderating effects of sample size, study setting, and publication type (for details see Table 4). Only a few study characteristics displayed moderating effects.

Satisfaction and customer engagement HiLMA results indicate that sample size and publication type significantly moderate the impact of satisfaction on customer engagement. Specifically, satisfaction-CE effects are stronger for small rather than large samples $(r$ large $=$ $\left..201 ; r_{\text {small }}=.521 ; p<.001\right)$. Additionally, as expected given publication bias expectations, published effects display larger effect sizes compared to unpublished papers $\left(r_{\text {published }}=.522 ; r\right.$ unpublished $=.242 ; p<.001)$.

Customer engagement and firm performance For the firm performance-CE path, only study setting and publication type display significant moderators. In particular, HiLMA results are consistent with a stronger CE-firm performance relationship in research using surveys rather than experiments $\left(r_{\text {experiment }}=.126 ; r_{\text {survey }}=.321 ; p<.05\right)$ and in published rather than unpublished studies $\left(r_{\text {published }}=.331 ; r_{\text {unpublished }}=.269 ; p<.001\right)$. No other moderating effects are suggested for the CE-firm performance path. For the behavioral intention-CE and WOMCE paths, no moderator achieved statistical significance.

\section{Discussion}




\section{Main findings and contributions}

Over the last decade or so, researchers have come to recognize that social media gives customers opportunities to better engage with products and brands (Hollebeek et al. 2014). Studies, however, suggest that customer engagement does not always lead to improved firm performance (Beckers et al. 2018). Meta-analytical methods allow researchers to draw more consistent conclusions from conflicting findings (Grewal et al. 2018). Thus, meta-analysis seems particularly relevant for the emerging evidence concerning customer engagement in social media (Hunter and Schmidt 2004; Lipsey and Wilson 2001). Our meta-analytic analysis of customer engagement in social media includes results from 97 studies reported between 2009 and 2019.

This research contributes to marketing theory by: synthesizing previous research, testing the conceptual framework of customer engagement in social media (CESM); suggesting a stronger role for trust in customer engagement vis-à-vis commitment, demonstrating that satisfaction and positive emotions are important mechanisms of customer engagement; emphasizing behavioral intention as an important outcome of customer engagement in driving (Vivek et al. 2012), and suggesting mechanisms through which customer engagement impacts firm performance. Exploratory moderation analysis also suggests the key moderators that may influence customer engagement effects (e.g., satisfaction-CE, CE-firm performance), including the type of social media and consumption value-type as novel moderators. Overall, we offer 10 key insights for customer engagement theory and practice, which are summarized in Table 5.

Insert Table 5 about here 
First, the meta-analytic results support the proposed framework of Customer Engagement in Social Media (CESM). A key feature of the model examination is the role of trust in creating customer satisfaction and driving customer engagement as previously hypothesized (Kumar et al. 2019; Pansari and Kumar 2017). Positive emotions strengthen customer engagement, but positive emotions do not serve as a mediator based on the results found here. Taken together, these findings provide support for a process where trust builds customer engagement directly and indirectly through satisfaction, with positive emotions playing a supporting and direct role, complementing previous conceptual research (Kumar et al. 2019; Pansari and Kumar 2017).

Second, our meta-analysis contributes by suggesting various mechanics through which customer engagement affects firm performance through conation, as captured in previous studies by behavioral intention, and the spread of WOM through social media (Algesheimer et al. 2005). Specifically, findings suggest that conation, as captured here through behavioral purchase/patronage intention, plays the lead role in facilitating positive firm-performance effects from customer engagement. Thus, we extend previous research positing the process under which customer engagement impacts firm performance (Kumar and Pansari 2015; Pansari and Kumar 2017). Surprisingly, while customer engagement is associated with increased WOM, model results suggest that WOM does not facilitate improved performance. The result is inconsistent with conventional wisdom regarding WOM through social media (e.g., Harvard Business Review 2019). Consequently, we can elaborate on Pansari and Kumar's (2017) definition of customer engagement by emphasizing the role of purchase-related behaviors as a key mechanism in leveraging engagement marketing into performance. 
Third, we explored a host of potential moderating factors. For instance, under conditions characterized by relatively high (vs. low) convenience consumption contexts, the satisfaction-CE path is more than twice as great. Perhaps brands associated with convenience goods or services benefit from more frequent encounters with customers and more frequent share of mind than in less convenient contexts; consequently, more opportunities to post satisfying experiences emerge. Less convenient contexts are probably more complicated and provide other avenues to increase or decrease customer engagement aside from satisfaction. In addition, results suggest that B2B firms exhibit a stronger satisfaction-CE path than do B2C firms. Perhaps, B2B firms tend to be more formally connected with customers through more structured relationship management programs. The positive partnerships between suppliers and customers may create more opportunities for mutually positive engagement.

Of particular interest, social media type moderates customer engagement processes as speculated previously (Beckers et al. 2018). In the Twitter space, the satisfaction-CE path is at least twice as strong as in other social media platform contexts. These findings might be explained because of Twitter's active and participatory role (Junco et al. 2010). Therefore, Twitter appears to be a convenient and accessible marketing tool for creating a stronger customer satisfaction-CE path.

Interestingly, the $\mathrm{CE}$-firm performance path is stronger for manufactured goods rather than for services. Customer engagement may be more diagnostic in the world of packaged goods in a manner similar to that of the convenience effects. Moreover, when customers are highly involved with hedonic rather than utilitarian consumption, customer engagement has about a three times greater impact on firm performance. These findings support the notion that customer engagement through hedonic experiences is particularly difficult for other firms to replicate 
relative to the more mundane utilitarian aspects of consumption (Babin et al. 1994; Bagozzi et al. 1999).

\section{Managerial implications}

Customer engagement attracts considerable managerial interest and the synthesis of previous findings offers practical conclusions. Now that technology is so influential in daily interactions between firms and customers, and that consumers are increasingly active in social media, managers must prioritize actions that directly enhance the customer engagement process (Baldus et al. 2015; Yadav and Pavlou 2014). Our meta-analytic results suggest that to enhance customer engagement in social media companies should focus on being perceived as trustworthy. Trust both relate directly to customer engagement and indirectly through its positive association with satisfaction. In contrast, commitment displays a relatively weak role in the formation of customer engagement through a small, positive, mediated effect through satisfaction. Further, any effort to build trust will directly pay off in higher customer engagement. To improve customers' trust, firms may work hard to be transparent in all their actions, for example. According to the most recent Harvard Business Review (2020) article on social media marketing, "trusted brands are more likely to attract business, and social media is a powerful tool to create engagement, gain feedback, and build trust with your audience."

The research suggests that positive emotions directly affect customer engagement but do not facilitate relationships from trust and commitment. Thus, their effect appears to be independent of other factors. We recommend that managers allocate resources toward more satisfying and pleasant touchpoints with customers as a way of enhancing customer engagement. While customer engagement (as key performance indicator itself) may justify such resource 
expenditures, as we see in the results, it is associated with other aspects of firm performance. For instance, the Four Seasons Hotels earned the number one travel and hospitality brand social ranking by earning not just more social media impressions, but by earning over $80 \%$ positive impressions (Netbase Social Analytics 2020). The high satisfaction and positive emotions of the Four Seasons experience get customers engaged and enhances firm performance.

The meta-analytic results suggest a particularly important role for Twitter vis-à-vis other social media platforms (Fischer and Reuber 2011; Junco et al. 2010). Moderation results suggest a stronger satisfaction-CE relationship via Twitter than other platforms. The quick and convenient interface through tweets provides an efficient mechanism for communicating through social networks. In contrast, other vehicles, such as Facebook are experiencing a drop of 50\% in customer engagement, mostly due to competition with informational news feeds and a lack of trust (Forbes 2018c). The role of Instagram is worthy of further research. Given that it is relatively new to the customer engagement scene, very few studies provide data in an Instagram context. However, its emergence as a particularly popular platform among younger consumers makes it worthy of attention.

Managerial practice suggests that convenience increases customer engagement, but our findings suggest a paradox. The relationship between satisfaction-CE is much stronger for high convenience contexts but the relationship between CE-firm performance is greater for low convenience contexts. The counterintuitive finding points to the need for further research to clarify the role of convenience on satisfaction-CE and CE-performance relationships. Additionally, results suggest a stronger CE-firm performance relationship for manufactured goods contexts. Brands may be more salient for tangible consumer goods and that increased brand salience may play a role in the stronger relationship relative to services where brands may 
be more fractionated and less distinct. Managerial practice suggests that services could increase tangibility to increase customer engagement (Forbes 2015) and, consequently, firm performance. Finally, another way to boost customer engagement contributions is to develop strategies that might increase the hedonic value of products and services. Thus, to potentialize CE effects on firm performance, firms could consider strategies to increase hedonic value (e.g., pleasure, fun, and adventure).

\section{Limitations and other directions for future research}

The present research has limitations that suggest avenues for further research. For example, the finding that trust plays an important role in creating customer engagement, but that commitment does not, deserves further attention. Indeed, given a strong correlation between trust and commitment observed over the studies in the review, attention may turn toward whether it is possible to build trust independent of building commitment? Meta-factor analysis might provide a tool useful in examining the potential for a lack of discriminant validity between trust and commitment. In any event, further synthesis of the trust-commitment relationship and the variants in its measurement is warranted.

Future studies could evaluate the role of emotions in the customer engagement framework more specifically. What conditions cause satisfaction to lead to CE rather than emotional bonding, and when are positive emotions more effective for creating $\mathrm{CE}$ in social media? Such investigations are crucial to determining whether the prevalence of social media has altered the need to regard satisfaction as a major consideration for marketing practice. Customer emotions are complex in terms of positive-versus-negative valence, approach-versus-avoidance orientation, and conflicting but similar emotions such as guilt versus shame (e.g., Han et al. 
2014; Labroo and Patrick 2009). Managers and public policymakers would benefit from future research that tests how different emotions affect customer engagement in social media because they often use emotional appeals to incentivize particular behaviors, such as improving consumers' health and safety choices (e.g., Agrawal et al. 2007). Further, the majority of research focuses on positive customer engagement. More attention is needed to examine negative customer engagement potentially driven by these various negative emotions.

As a review, we were limited by the nature of the data in previous studies. Facebook and blogs were found to be two times less effective than Twitter for creating customer engagement. Twitter relies more on informational content (the famous 140 text characters) rather than images. Do the results hold for other image-based social media platforms such as Instagram? In social media contexts, is "a picture worth a thousand words," or will consumers consider the text to be more engaging than images?

Our meta-analytical findings indicate that low convenience may be associated with stronger customer engagement effects on firm performance, which is counterintuitive to longstanding marketing practice and theory. Further studies should focus on the interplay between convenience and customer engagement to examine whether changes in convenience in social media environments could boost firm performance. Similarly, research needs to sort out the relative role of involvement versus convenience vis-à-vis customer engagement.

Customer engagement in social media is a relatively new phenomenon, and more research is needed to explore how the emerging forms of social media affect customer engagement. For example, Vero focuses on original brand content and organic customer connections. Facecast uses random live video chats that focus on fun. Caffeine allows customers to enjoy real-time engagement. Frameplay interjects opportunities for customer engagement 
within video games. Future research could consider whether these new forms of social media interaction will enhance customer engagement effects.

Our research was limited to relationships commonly studied in the marketing literature. Some relationships have received very little empirical attention beyond the specific negative emotions mentioned above. Given that feedback effects have received scant empirical attention in the marketing literature, we did not include them in the meta-analysis. As the empirical literature builds more evidence, future quantitative syntheses may be able to address such effects.

Finally, our meta-analytic focus was on synthesizing previous findings within a model of customer engagement and did not directly address its measurement. We presumed that the variables the authors referred to as "customer (or consumer) engagement" measured that concept. However, the measurement varies considerably. The customer engagement construct depends on relationship formation (antecedents like trust, satisfaction, and positive emotions), customer engagement creation (CE construct itself), and customer engagement contributions (behavioral intentions, WOM, and firm performance). Thus, when others present customer engagement measures that share greater similarity with attitudinal or behavioral constructs, a lack of discriminant validity might be expected (Obilo, Chefor, and Saleh 2020). Future research should examine the distinctiveness of customer engagement as a latent factor relative to other concepts. Further, we would not consider the CESM results presented here as definitive by any means. Future research can elaborate further and more closely examine its mechanics as research continues to develop.

\section{Conclusion}


In the end, customer engagement will likely continue as an important topic in the academic marketing literature. The synthesis presented here helps to focus on the overall findings and points to some areas in need of further research. Not the least of other reasons is the distinctiveness of customer engagement as a factor as clearly various definitions conflict and/or overlap with other well-established concepts (Obilo et al. 2020). But, the synthesized results suggest that to look at customer engagement in isolation of other factors minimizes its importance. The notion of customer engagement "mechanics" (Pansari and Kumar 2017) emphasizes the role that emotion and trust play in driving customer activities, with conative behaviors that involve purchase being paramount, that enhance the value of both buyer and seller.

\section{References}

Aggarwal, R., Gopal, R., Gupta, A., \& Singh, H. (2012). Putting money where the mouths are: The relation between venture financing and electronic word-of-mouth. Information Systems Research, 23(3-part-2), 976-992.

Agrawal, N., Menon, G., \& Aaker, J. L. (2007). Getting Emotional About Health. Journal of Marketing Research, 44(1), 100-113.

Algesheimer, R., Dholakia, U. M., \& Herrmann, A. (2005). The social influence of brand community: Evidence from European car clubs. Journal of Marketing, 69(3), 19-34.

Ashley, C., \& Tuten, T. (2015). Creative strategies in social media marketing: An exploratory study of branded social content and consumer engagement. Psychology \& Marketing, $32(1), 15-27$. 
Babić-Rosario, A., Sotgiu, F., De Valck, K., \& Bijmolt, T. H. (2016). The effect of electronic word of mouth on sales: A meta-analytic review of platform, product, and metric factors. Journal of Marketing Research, 53(3), 297-318.

Babin, B. J., Darden, W. R., \& Griffin, M. (1994). Work and/or fun: measuring hedonic and utilitarian shopping value. Journal of Consumer Research, 20(4), 644-656.

Badrinarayanan, V. A., Sierra, J. J., \& Martin, K. M. (2015). A dual identification framework of online multiplayer video games: The case of massively multiplayer online role playing games (MMORPGs). Journal of Business Research, 68(5), 1045-1052.

Bagozzi, R. P., Gopinath, M., \& Nyer, P. U. (1999). The Role of Emotions in Marketing. Journal of the Academy of Marketing Science, 27, 184-206.

Baldus, B. J., Voorhees, C., \& Calantone, R. (2015). Online brand community engagement: Scale development and validation. Journal of Business Research, 68(5), 978-985.

Beckers, S. F. M., van Doorn, J., \& Verhoef, P. C. (2018). Good, better, engaged? The effect of company-initiated customer engagement behavior on shareholder value. Journal of the Academy of Marketing Science, 46(3), 366-383.

Bijmolt, T. H. A., Leeflang, P. S. H., Block, F., Eisenbeiss, M., Hardie, B. G. S., Lemmens, A., \& Saffert, P. (2010). Analytics for Customer Engagement. Journal of Service Research, $13(3), 341-356$.

Borenstein, M., Hedges, L. V., Higgins, J. P., \& Rothstein, H. R. (2019). Introduction to metaanalysis. UK: John Wiley \& Sons.

Bowden, J. L. H. (2009a). The process of customer engagement: A conceptual framework. Journal of Marketing Theory and Practice, 17(1), 63-74. 
Bowden, J. L. H. (2009b). Customer engagement: A framework for assessing customer-brand relationships: The case of the restaurant industry. Journal of Hospitality Marketing \& Management, 18(6), 574-596.

Brodie, R. J., Ilic, A., Juric, B., \& Hollebeek, L. (2013). Consumer engagement in a virtual brand community: An exploratory analysis. Journal of Business Research, 66(1), 105-114.

Brodie, R. J., Hollebeek, L. D., Jurić, B., \& Ilić, A. (2011). Customer engagement: Conceptual domain, fundamental propositions, and implications for research. Journal of Service Research, 14(3), 252-271.

Brown, L. G. (1990). Convenience in Services Marketing. Journal of Services Marketing, 4(1), $53-59$.

Calder, B. J., Malthouse, E. C., \& Schaedel, U. (2009). An experimental study of the relationship between online engagement and advertising effectiveness. Journal of Interactive Marketing, 23(4), 321-331.

Cheung, M. W. (2015). Meta-Analysis: A Structural Equation Modeling Approach. Wiley.

Cheung, M. W., \& Chan, W. (2005). Meta-analytic structural equation modeling: a two-stage approach. Psychological Methods, 10(1), 40-64.

Cheung, C. M., Shen, X. L., Lee, Z. W., \& Chan, T. K. (2015). Promoting sales of online games through customer engagement. Electronic Commerce Research and Applications, 14(4), 241-250.

Chu, S. C., \& Kim, Y. (2011). Determinants of consumer engagement in electronic word-ofmouth (eWOM) in social networking sites. International Journal of Advertising, 30(1), 47-75. 
Claffey, E., \& Brady, M. (2017). Examining Consumers' Motivations to Engage in Firm-Hosted Virtual Communities. Psychology \& Marketing, 34(4), 356-375.

Dessart, L., Veloutsou, C., \& Morgan-Thomas, A. (2015). Consumer engagement in online brand communities: a social media perspective. Journal of Product \& Brand Management, 24(1), 28-42.

Dutot, V., \& Mosconi, E. (2016). Understanding factors of disengagement within a virtual community: an exploratory study. Journal of Decision Systems, 25(3), 227-243.

Eisend, M. (2017). The Third-Person Effect in Advertising: A Meta-Analysis. Journal of Advertising, 46(3), 377-394.

Fischer, E., \& Reuber, A. R. (2011). Social interaction via new social media:(How) can interactions on Twitter affect effectual thinking and behavior?. Journal of Business Venturing, 26(1), 1-18.

Forbes. (2015). How To Sell Intangibles. Retrieved July 1 ${ }^{\text {st }}, 2019$ from https://www.forbes.com/sites/larrymyler/2015/08/15/how-to-sellintangibles/\#572772477a0a

Forbes. (2018a). Want to Improve Your Social Media Strategy? Avoid These 14 Faux Pas. Retrieved July $1^{\text {st }}, 2019$ from https://www.forbes.com/sites/forbesagencycouncil/2018/04/27/want-to-improve-yoursocial-media-strategy-avoid-these-14-faux-pas/\#4178216574d6

Forbes. (2018b). Social Media is Increasing Brand Engagement and Sales. Retrieved July $1^{\text {st }}$, 2019 from https://www.forbes.com/sites/tjmccue/2018/06/26/social-media-is-increasingbrand-engagement-and-sales/\#35a844717cb3 
Forbes. (2018c). Facebook Engagement Sharply Drops 50\% Over Last 18 Months. Retrieved July $1^{\text {st }}, 2019$ https://www.forbes.com/sites/ryanerskine/2018/08/13/study-facebookengagement-sharply-drops-50-over-last-18-months/\#58a6828b94e8

Forbes (2019). Creating a Marketing Budget for 2020. Retrieved April 1st, 2020 from https://www.forbes.com/sites/theyec/2019/12/19/creating-a-marketing-budget-for-2020/ Forbes (2020a). Why 2020 is a Critical Global Tipping Point for Social Media. Retrieved April 1st, 2020 from https://www.forbes.com/sites/johnkoetsier/2020/02/18/why-2020-is-acritical-global-tipping-point-for-social-media/

Forbes (2020b). Top Ten Results from the February 2020 CMO Survey. Retrieved April 1st, 2020 from https://www.forbes.com/sites/christinemoorman/2020/02/26/top-ten-resultsfrom-the-february-2020-cmo-survey/

Geyskens, I., Krishnan, R., Steenkamp, J. B. E., \& Cunha, P. V. (2009). A review and evaluation of meta-analysis practices in management research. Journal of Management, 35(2), 393419.

Geyskens, I., Steenkamp, J. B. E., \& Kumar, N. (1999). A meta-analysis of satisfaction in marketing channel relationships. Journal of Marketing Research, 36(2), 223-238.

Grewal, D., Puccenelli, N., \& Monroe, K. B. (2018). Meta-analysis: integrating accumulated knowledge. Journal of the Academy of Marketing Science, 46, 9-30.

Gummerus, J., Liljander, V., Weman, E., \& Pihlström, M. (2012). Customer engagement in a Facebook brand community. Management Research Review, 35(9), 857-877.

Gustafsson, A., Johnson, M. D., \& Roos, I. (2005). The effects of customer satisfaction, relationship commitment dimensions, and triggers on customer retention. Journal of Marketing, 69(4), 210-218. 
Hagtvedt, H., \& Patrick, V. M. (2009). The broad embrace of luxury: Hedonic potential as a driver of brand extendibility. Journal of Consumer Psychology, 19(4), 608-618.

Hair, J. F., Jr, Babin, B. J., \& Krey, N. (2017). Covariance-Based Structural Equation Modeling in the Journal of Advertising: Review and Recommendations. Journal of Advertising, 46(1), 163-177.

Halaszovich, T., \& Nel, J. (2017). Customer-brand engagement and Facebook fan-page "Like"intention. Journal of Product \& Brand Management, 26(2), 120-134.

Han, D., Duhachek, A. and Agrawal, N. (2014), Emotions Shape Decisions through Construal Level: The Case of Guilt and Shame, Journal of Consumer Research, 41(4), 1047-1064.

Harmeling, C. M., Moffett, J. W., Arnold, M. J., \& Carlson, B. D. (2017). Toward a theory of customer engagement marketing. Journal of the Academy of Marketing Science, 45(3), $312-335$.

Harvard Business Review. (2018). The Basic Social Media Mistakes Companies Still Make. Retrieved July $1^{\text {st }}, 2018$ from https://hbr.org/2018/01/the-basic-social-media-mistakescompanies-still-make

Harvard Business Review. (2019). Using Social Media to Connect With Your Most Loyal Customers. Retrieved January $15^{\text {th }}, 2020$ from https://hbr.org/2019/12/using-socialmedia-to-connect-with-your-most-loyal-customers

Harvard Business Review. (2020). Four Questions to Boost Your Social Media Marketing. Retrieved January $15^{\text {th }}, 2020$ from https://hbr.org/2020/01/4-questions-to-boost-yoursocial-media-marketing 
Hauk, N., Hüffmeier, J., \& Krumm, S. (2018). Ready to be a silver surfer? A meta-analysis on the relationship between chronological age and technology acceptance. Computers in Human Behavior, 84, 304-319.

Hedges, L.V., \& Olkin, I. (1985). Statistical methods for meta-analysis. Orlando, FL: Academic Press.

Hennig-Thurau, T., Qwinner, P. K., Walsh, G., \& Gremler, D. D. (2004). Electronic word-ofmouth via consumer-opinion platforms: What motivates consumers to articulate themselves on the Internet? Journal of Interactive Marketing, 18, 38-52.

Higgins, E. T., \& Scholer, A. A. (2009). Engaging the consumer: The science and art of the value creation process. Journal of Consumer Psychology, 19(2), 100-114.

Hirschman, E. C., \& Holbrook, M. B. (1982). Hedonic consumption: emerging concepts, methods and propositions. Journal of Marketing, 46, 92-101.

Hollebeek, L. (2011). Exploring customer brand engagement: definition and themes. Journal of Strategic Marketing, 19(7), 555-573.

Hollebeek, L. D. (2019). Developing business customer engagement through social media engagement-platforms: an integrative SD logic/RBV-informed model. Industrial Marketing Management, 81, 89-98.

Hollebeek, L. D., Glynn, M. S., \& Brodie, R. J. (2014). Consumer brand engagement in social media: Conceptualization, scale development and validation. Journal of Interactive Marketing, 28(2), 149-165.

Hollebeek, L. D., Srivastava, R. K., \& Chen, T. (2016). SD logic-informed customer engagement: integrative framework, revised fundamental propositions, and application to CRM. Journal of the Academy of Marketing Science, 47, 1-25. 
Hopp, T., \& Gallicano, T. D. (2016). Development and test of a multidimensional scale of blog engagement. Journal of Public Relations Research, 28(3-4), 127-145.

Hunter, J. E., \& Schmidt, F. L. (2004). Methods of meta-analysis: Correcting error and bias in research findings. SAGE Publications.

Jak, S. (2015). Meta-analytic structural equation modelling. Dordrecht, Neth: Springer.

Junco, R., Elavsky, C. M., \& Heiberger, G. (2013). Putting twitter to the test: Assessing outcomes for student collaboration, engagement and success. British Journal of Educational Technology, 44(2), 273-287.

Kim, Y., \& Peterson, R. A. (2017). A Meta-analysis of Online Trust Relationships in Ecommerce. Journal of Interactive Marketing, 38, 44-54.

Kumar, V. (2013). Profitable Customer Engagement - Concept, Metrics and Strategies. SAGE Publications.

Kumar, V., Aksoy, L., Donkers, B., Venkatesan, R., Wiesel, T., \& Tillmanns, S. (2010). Undervalued or overvalued customers: capturing total customer engagement value. Journal of Service Research, 13(3), 297-310.

Kumar, V., \& Pansari, A. (2015). Measuring the benefits of employee engagement. MIT Sloan Management Review, 56(4), 67.

Kumar, V., Rajan, B., Gupta, S., \& Pozza, I. D. (2019). Customer engagement in service. Journal of the Academy of Marketing Science, 47(1), 138-160. 
Labrecque, L. I. (2014). Fostering Consumer-Brand Relationships in Social Media

Environments: The Role of Parasocial Interaction. Journal of Interactive Marketing, 28, 134-148.

Labroo, A., \& Patrick, V. M. (2009). Why Happiness Helps You See the Big Picture, Journal of Consumer Research, 35(5), 800-809.

Lipsey, M. W. \& Wilson, D. B. (2001). Practical meta-analysis (Vol. 49). Thousand Oaks, CA: SAGE Publications.

Mano, H., \& Oliver, R. L. (1993). Assessing the dimensionality and structure of the consumption experience: Evaluation, feeling, and satisfaction. Journal of Consumer Research, 20(3), 451-466.

Moher, D., Liberati, A., Tetzlaff, J., Altman, D. G. (2009). Preferred Reporting Items for Systematic Reviews and Meta-Analyses: The PRISMA Statement. PLoS Med, 6(7), e1000097.

Mollen, A., \& Wilson, H. (2010). Engagement, telepresence, and interactivity in online consumer experience: Reconciling scholastic and managerial perspectives. Journal of Business Research, 63(9), 919-925.

Moorman, C., Deshpande, R., \& Zaltman, G. (1993). Factors affecting trust in market research relationships. Journal of Marketing, 57(1),81-101.

Morgan, N. A., \& Rego, L. L. (2006). The value of different customer satisfaction and loyalty metrics in predicting business performance. Marketing Science, 25(5), 426-439.

Morgan, R. M., \& Hunt, S. D. (1994). The commitment-trust theory of relationship marketing. Journal of Marketing, 58(3), 20-38. 
Neale, M. C., Hunter, M. D., Pritikin, J. N., Zahery, M., Brick, T. R., Kirkpatrick, R. M., ... \& Boker, S. M. (2016). OpenMx 2.0: Extended structural equation and statistical modeling. Psychometrika, 81(2), 535-549.

Netbase Social Analytics. (2020). Social Media Rankings by Industry. Retrieved January $15^{\text {th }}$, 2020 from https://www.netbase.com/social-media-rankings/

Obilo, O. O., Chefor, E., \& Saleh, A. (2020). Revisiting the consumer brand engagement concept. Journal of Business Research, In Press. https://doi.org/10.1016/j.jbusres.2019.12.023

Pansari, A., \& Kumar, V. (2017). Customer engagement: the construct, antecedents, and consequences. Journal of the Academy of Marketing Science, 45(3), 294-311.

Park, C. W., \& MacInnis, D. J. (2006). What's in and what's out: Questions on the boundaries of the attitude construct. Journal of Consumer Research, 33(1), 16-18.

Paruthi, M., \& Kaur, H. (2017). Scale Development and Validation for Measuring Online Engagement. Journal of Internet Commerce, 16(2), 127-147.

Peterson, R. A., \& Brown, S. P. (2005). On the use of beta coefficients in meta-analysis. Journal of Applied Psychology, 90(1), 175.

Rietveld, R., van Dolen, W., Mazloom, M., \& Worring, M. (2020). What You Feel, Is What You Like Influence of Message Appeals on Customer Engagement on Instagram. Journal of Interactive Marketing, 49, 20-53.

Rosenblad, A. (2009). Introduction to Meta- Analysis by Michael Borenstein, Larry V. Hedges, Julian PT Higgins, Hannah R. Rothstein. International Statistical Review, 77(3), 478-479.

Rosenthal, R. (1979). The file drawer problem and tolerance for null results. Psychological Bulletin, 86(3), 638-642. 
Rosenthal, R., \& DiMatteo, M. R. (2001). Meta-analysis: Recent developments in quantitative methods for literature reviews. Annual Review of Psychology, 52(1), 59-82.

Rust, R. T., \& Cooil, B. (1994). Reliability measures for qualitative data: Theory and implications. Journal of Marketing Research, 31(1), 1-14.

Santini, F., Ladeira, W. J., Sampaio, C. H., \& Pinto, D. C. (2018). The brand experience extended model: a meta-analysis. Journal of Brand Management, 25, 519-535.

See-To, E. W., \& Ho, K. K. (2014). Value co-creation and purchase intention in social network sites: The role of electronic Word-of-Mouth and trust-A theoretical analysis. Computers in Human Behavior, 31, 182-189.

Simon, F., \& Tossan, V. (2018). Does brand-consumer social sharing matter? A relational framework of customer engagement to brand-hosted social media. Journal of Business Research, 85, 175-184.

Smith, J. B., \& Colgate, M. (2007). Customer value creation: a practical framework. Journal of marketing Theory and Practice, 15(1), 7-23.

Sprott, D., Czellar, S., \& Spangenberg, E. (2009). The importance of a general measure of brand engagement on market behavior: Development and validation of a scale. Journal of Marketing Research, 46(1), 92-104.

Thomson, M., MacInnis, D. J., \& Whan Park, C. (2005). The ties that bind: Measuring the strength of consumers' emotional attachments to brands. Journal of Consumer Psychology, 15(1), 77-91.

Trusov, M., Bucklin, R. E., \& Pauwels, K. (2009). Effects of word-of-mouth versus traditional marketing: findings from an internet social networking site. Journal of Marketing, 73(5), 90-102. 
Tsai, H. T., Huang, H. C., \& Chiu, Y. L. (2012). Brand community participation in Taiwan: Examining the roles of individual-, group-, and relationship-level antecedents. Journal of Business Research, 65(5), 676-684.

Van Doorn, J., Lemon, K. N., Mittal, V., Nass, S., Pick, D., Pirner, P., \& Verhoef, P. C. (2010). Customer engagement behavior: Theoretical foundations and research directions. Journal of Service Research, 13(3), 253-266.

Van Lange, P. A. M., Rusbult, C. E., Drigotas, S. M., \& Arriaga, X. B. (1997). Willingness to sacrifice in close relationships. Journal of Personality and Social Psychology, 72(6), $1373-1395$.

Venkatesan, R. (2017). Executing on a customer engagement strategy. Journal of Marketing Theory and Practice, 45(3), 289-293.

Verhoef, P. C., Franses, P. H., \& Hoekstra, J. C. (2002). The effect of relational constructs on customer referrals and number of services purchased from a multiservice provider: does age of relationship matter?. Journal of the Academy of Marketing Science, 30(3), 202.

Verhoef, P. C., Reinartz, W. J., \& Krafft, M. (2010). Customer engagement as a new perspective in customer management. Journal of Service Research, 13(3), 247-252.

Viechtbauer W. (2010) Conducting meta-analyses in R with the metafor package. Journal of Statistical Software, 36, 1-48

Villanueva, J., Yoo, S., \& Hanssens, D. M. (2008). The impact of marketing-induced versus word-of-mouth customer acquisition on customer equity growth. Journal of Marketing Research, 45(1), 48-59. 
Vivek, S. D., Beatty, S. E., \& Morgan, R. M. (2012). Customer engagement: Exploring customer relationships beyond purchase. Journal of Marketing Theory and Practice, 20(2), 122146.

Wang, Z., \& Kim, H. G. (2017). Can social media marketing improve customer relationship capabilities and firm performance? Dynamic capability perspective. Journal of Interactive Marketing, 39, 15-26.

Wong, H. Y., \& Merrilees, B. (2015). An empirical study of the antecedents and consequences of brand engagement. Marketing Intelligence \& Planning, 33(4), 575-591.

Yadav, M. S., \& Pavlou, P. A. (2014). Marketing in computer-mediated environments: Research synthesis and new directions. Journal of Marketing, 78(1), 20-40.

Zboja, J. J., \& Voorhees, C. M. (2006). The impact of brand trust and satisfaction on retailer repurchase intentions. Journal of Services Marketing, 20(6), 381-390.

Zaichkowsky, J. L. (1985). Measuring the involvement construct. Journal of Consumer Research, 12(3), 341-352.

Zeithaml, V. A., Parasuraman, A., \& Berry, L. L. (1985). Problems and strategies in services marketing. Journal of Marketing, 49(2), 33-46.

Zenith Media (2020). Social media overtakes print to become the third-largest advertising channel. Retrieved April 1st, 2020 from https://www.zenithmedia.com/social-mediaovertakes-print-to-become-the-third-largest-advertising-channel/ 
Figure 1 - Framework of Customer Engagement in Social Media (CESM)

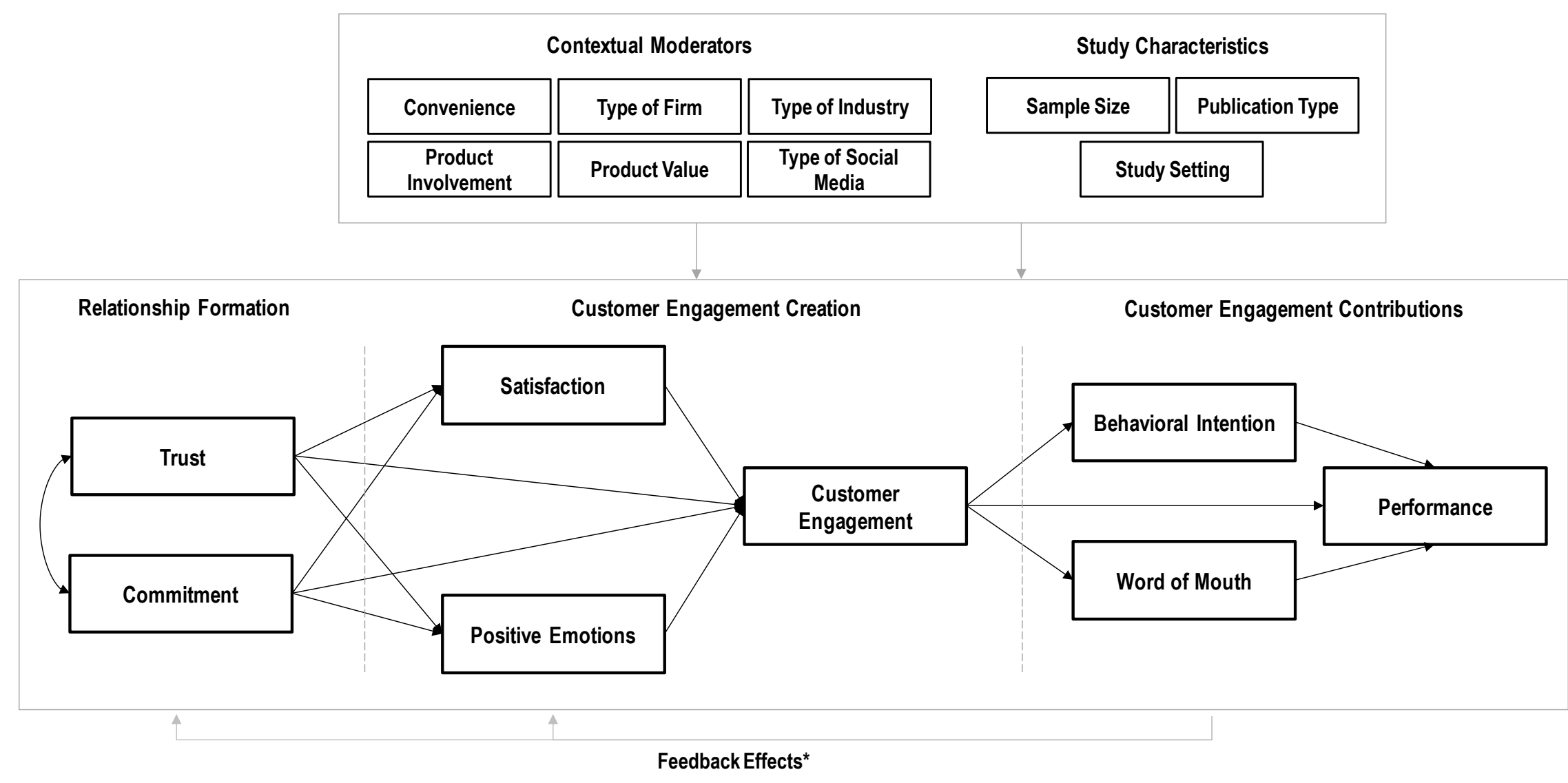

Notes. Feedback effects are not formally examined in this meta-analysis. Although feedback effects are theoretically important, the lack of existing studies looking at these effects precludes a meaningful empirical investigation of them here (please see the limitations and future research section). 
Figure 2 - MASEM Results (ML Estimates)

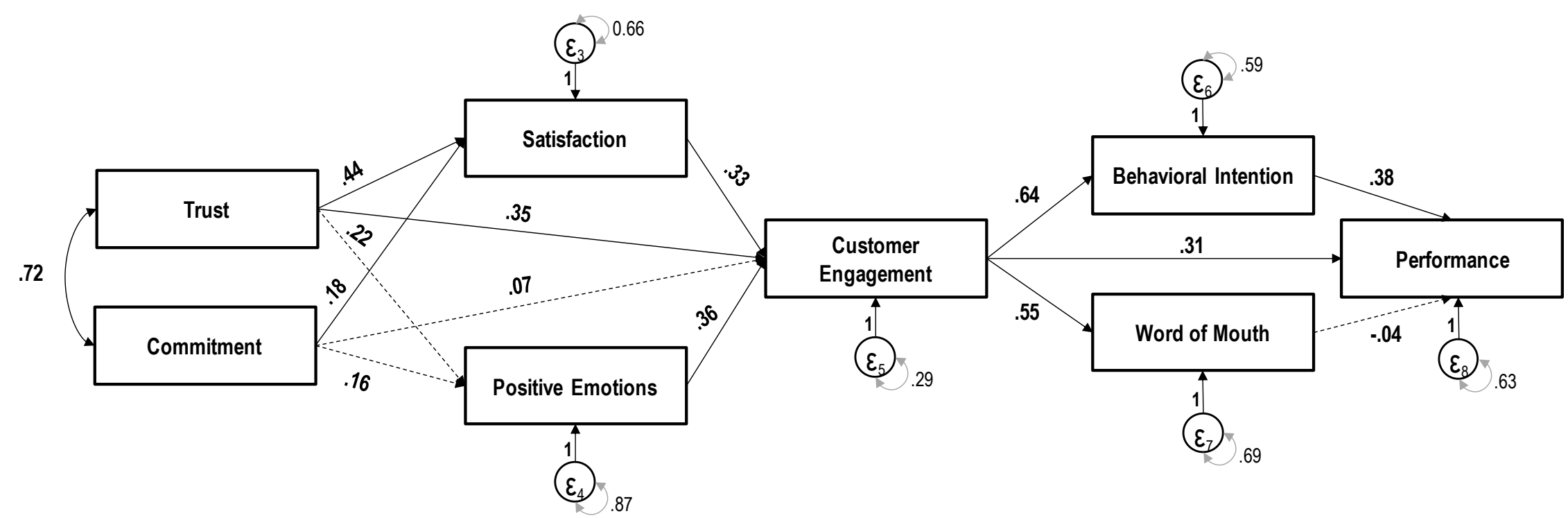

Notes. Solid lines represent significant paths, whereas the dotted lines indicate non-significant paths. 
Table 1 - Coding Procedure in the Meta-Analysis

\begin{tabular}{|c|c|c|}
\hline Variable & Moderators Description & Coding* \\
\hline \multicolumn{3}{|c|}{ Contextual Characteristics } \\
\hline Convenience & $\begin{array}{l}\text { Convenience is linked with the time and effort that customers invest to purchase a product or } \\
\text { service (Brown 1990). We coded the type of product/service in studies into low }(N=30) \text { and high } \\
(N=36) \text { convenience. }\end{array}$ & $\begin{array}{l}0=\text { Low } \\
1=\text { High }\end{array}$ \\
\hline Type of Firm & $\begin{array}{l}\text { B2B contexts compared to B2C tend to evoke more functional aspects and has a more complex } \\
\text { decision-making (Pansari and Kumar 2017). Studies were coded as B2C }(N=38) \text { or B2B }(N=6) \text {. }\end{array}$ & $\begin{array}{l}0=B 2 B \\
1=B 2 C\end{array}$ \\
\hline $\begin{array}{l}\text { Type of } \\
\text { Industry }\end{array}$ & $\begin{array}{l}\text { A dummy variable indicate whether the studies were applied in a product (manufacturing) }(N= \\
\text { 18) or a service }(N=37) \text { context. }\end{array}$ & $\begin{array}{l}0=\text { Service } \\
1=\text { Manufacturing }\end{array}$ \\
\hline $\begin{array}{l}\text { Product } \\
\text { Involvement }\end{array}$ & $\begin{array}{l}\text { Product involvement refers to consumer's perceptions about the relevance of products or } \\
\text { services that are linked with individual needs, values, and interests (Zaichkowsky 1985). We } \\
\text { coded product involvement as high ( } N=31) \text { or low }(N=26) \text { based on the type of } \\
\text { products/services mentioned in the studies. }\end{array}$ & $\begin{array}{l}0=\text { Low } \\
1=\text { High }\end{array}$ \\
\hline Product Value & $\begin{array}{l}\text { Product value was classified as hedonic }(N=25) \text { or utilitarian }(N=23) \text { based on the product's } \\
\text { information obtained in the methodological section of each study. }\end{array}$ & $\begin{array}{l}0=\text { Utilitarian } \\
1=\text { Hedonic }\end{array}$ \\
\hline $\begin{array}{l}\text { Type of Social } \\
\text { Media }\end{array}$ & $\begin{array}{l}\text { Three types of social media were identified in the studies used in this meta-analysis: Blog }(N=6) \text {, } \\
\text { Facebook }(N=36) \text { and; Twitter }(N=7) \text {. }\end{array}$ & $\begin{array}{l}1=\text { Blog } \\
2=\text { Facebook } \\
3=\text { Twitter }\end{array}$ \\
\hline \multicolumn{3}{|c|}{ Study Characteristics } \\
\hline Sample Size & $\begin{array}{l}\text { We defined the sample in two groups, small }(N=65) \text { or large }(N=59) \text {, from the sample size } \\
\text { declared in each study. We adopt the median of the sample sizes as the cut-off point. }\end{array}$ & $\begin{array}{l}0=\text { Small } \\
1=\text { Large }\end{array}$ \\
\hline Study Setting & $\begin{array}{l}\text { The study setting was coded by survey }(N=18) \text { or experiment }(N=113) \text {. This information was } \\
\text { obtained from a methodological section of individual studies. }\end{array}$ & $\begin{array}{l}0=\text { Survey } \\
1=\text { Experiment }\end{array}$ \\
\hline $\begin{array}{l}\text { Publication } \\
\text { Type }\end{array}$ & $\begin{array}{l}\text { We identified the publication type by published scientific papers in journals }(N=99) \text { or } \\
\text { unpublished theses, congresses or working papers }(N=34) \text {. }\end{array}$ & $\begin{array}{l}0=\text { Published } \\
1=\text { Unpublished }\end{array}$ \\
\hline
\end{tabular}

Notes: *Three independent judges carried out the coding of studies. Moderators sample sizes indicate the sum of coded items for satisfaction, positive emotions, and firm performance. We also explored moderation by brand value (high vs. low), cultural orientation (Western vs. Eastern), Human Development Index (high vs. low), sample type (students vs. non-students), publication ranking (high vs. low), engagement scale (Algesheimer, Calder, Hollebeek, Baldus), scale items (several vs. few), and engagement theory origin (yes vs. no). However, no significant moderation among these emerged. Further, when authors used a multidimensional representation of $\mathrm{CE}$, we averaged over the correlations to get a single aggregate correlation for use in statistical analyses. 
Table 2 - Correlation Matrix

\begin{tabular}{|c|c|c|c|c|c|c|c|c|}
\hline Constructs & Trust & Commitment & Satisfaction & $\begin{array}{l}\text { Positive } \\
\text { emotion }\end{array}$ & $\begin{array}{c}\text { Customer } \\
\text { Engagement }\end{array}$ & $\begin{array}{l}\text { Behavioral } \\
\text { Intention }\end{array}$ & WOM & $\begin{array}{c}\text { Firm } \\
\text { Performance }\end{array}$ \\
\hline Trust & 1 & & & & & & & \\
\hline Commitment & 0.735 & 1 & & & & & & \\
\hline Satisfaction & 0.536 & 0.486 & 1 & & & & & \\
\hline Positive emotion & 0.323 & 0.312 & 0.603 & 1 & & & & \\
\hline $\begin{array}{l}\text { Customer } \\
\text { Engagement }\end{array}$ & 0.530 & 0.635 & 0.141 & 0.596 & 1 & & & \\
\hline $\begin{array}{l}\text { Behavioral } \\
\text { Intention }\end{array}$ & 0.443 & 0.420 & 0.525 & 0.398 & 0.520 & 1 & & \\
\hline WOM & 0.578 & 0.265 & 0.492 & 0.208 & 0.519 & 0.360 & 1 & \\
\hline Firm Performance & 0.470 & 0.593 & 0.209 & 0.306 & 0.433 & 0.571 & 0.276 & 1 \\
\hline
\end{tabular}


Table 3 - MASEM Results and Mediation Analysis (ML Estimates)

\begin{tabular}{|c|c|c|c|c|c|c|}
\hline Independent Variable & $\rightarrow$ & Dependent Variable & Estimate & $\mathrm{LCl}$ & $\mathrm{UCl}$ & $P$ \\
\hline \multicolumn{7}{|c|}{ Antecedents of Customer Engagement } \\
\hline Trust & $\rightarrow$ & Satisfaction & 0.440 & 0.158 & 0.723 & .01 \\
\hline Commitment & $\rightarrow$ & Satisfaction & 0.179 & 0.008 & 0.349 & .05 \\
\hline Trust & $\rightarrow$ & Positive emotions & 0.216 & -0.050 & 0.482 & NS \\
\hline Commitment & $\rightarrow$ & Positive emotions & 0.160 & -0.057 & 0.378 & NS \\
\hline Satisfaction & $\rightarrow$ & Customer Engagement & 0.327 & 0.154 & 0.500 & .001 \\
\hline Positive emotions & $\rightarrow$ & Customer Engagement & 0.357 & 0.276 & 0.438 & .001 \\
\hline Trust & $\rightarrow$ & Customer Engagement & 0.352 & 0.201 & 0.504 & .001 \\
\hline Commitment & $\rightarrow$ & Customer Engagement & 0.074 & -0.120 & 0.269 & NS \\
\hline \multicolumn{7}{|c|}{ Consequents of Customer Engagement } \\
\hline Customer Engagement & $\rightarrow$ & Behavioral intention & 0.641 & 0.592 & 0.690 & .001 \\
\hline Customer Engagement & $\rightarrow$ & Word-of-Mouth & 0.555 & 0.511 & 0.599 & .001 \\
\hline Customer Engagement & $\rightarrow$ & Performance & 0.313 & 0.169 & 0.457 & .001 \\
\hline Behavioral intention & $\rightarrow$ & Performance & 0.378 & 0.249 & 0.507 & .001 \\
\hline Word-of-Mouth & $\rightarrow$ & Performance & -0.036 & -0.125 & 0.053 & NS \\
\hline \multicolumn{7}{|l|}{ Covariances } \\
\hline Trust & $<>$ & Commitment & 0.719 & 0.646 & 0.792 & .001 \\
\hline \multicolumn{3}{|c|}{ Indirect Effects through Satisfaction } & Estimate & $\mathrm{LCl}$ & $\mathrm{UCl}$ & $P^{*}$ \\
\hline \multicolumn{3}{|c|}{ Trust $\rightarrow$ Satisfaction $\rightarrow$ CE } & 0.144 & 0.060 & 0.271 & .05 \\
\hline \multicolumn{3}{|c|}{ Commitment $\rightarrow$ Satisfaction $\rightarrow$ CE } & 0.059 & 0.015 & 0.172 & .05 \\
\hline \multicolumn{3}{|c|}{ Indirect Effects through Positive emotions } & Estimate & $\mathrm{LCl}$ & $\mathrm{UCl}$ & $P^{*}$ \\
\hline \multicolumn{3}{|c|}{ Trust $\rightarrow$ Positive emotions $\rightarrow$ CE } & 0.077 & -0.033 & 0.137 & NS \\
\hline \multicolumn{3}{|c|}{ Commitment $\rightarrow$ Positive emotions $\rightarrow$ CE } & 0.057 & -0.007 & 0.125 & NS \\
\hline \multicolumn{3}{|c|}{ Indirect Effects of CE on Performance } & Estimate & $\mathrm{LCl}$ & $\mathrm{UCl}$ & $P^{*}$ \\
\hline \multicolumn{3}{|c|}{$\mathrm{CE} \rightarrow$ Behavioral Intention $\rightarrow$ Performance } & 0.243 & 0.153 & 0.337 & .05 \\
\hline \multicolumn{3}{|c|}{$\mathrm{CE} \rightarrow$ WOM $\rightarrow$ Performance } & -0.020 & -0.074 & 0.025 & NS \\
\hline
\end{tabular}

Notes: P-values of mediation analysis are based on $95 \%$ likelihood-based confidence intervals and the saturated model, as per Jak's (2015) indirect effects procedure for metaSEM (Cheung, 2015). 
Table 4 - Potential Moderators of Customer Engagement Effects

\begin{tabular}{|c|c|c|c|c|c|}
\hline \multirow{2}{*}{$\begin{array}{l}\text { Contextual } \\
\text { Moderators }\end{array}$} & \multirow[t]{2}{*}{ Level } & \multicolumn{2}{|c|}{ Satisfaction-CE } & \multicolumn{2}{|c|}{$\begin{array}{c}\text { Firm } \\
\text { Performance-CE }\end{array}$} \\
\hline & & $b$ & $r$ & $B$ & $r$ \\
\hline \multirow[t]{2}{*}{ Convenience } & High & 1 & .629 & 1 & .211 \\
\hline & Low & $-.649^{*}$ & .235 & $.130^{* * *}$ & .262 \\
\hline \multirow[t]{2}{*}{ Type of Firm } & $B 2 C$ & 1 & .250 & - & - \\
\hline & $B 2 B$ & $-.349^{*}$ & .543 & - & - \\
\hline \multirow[t]{2}{*}{ Type of Industry } & Manufacturing & 1 & .431 & 1 & .333 \\
\hline & Service & .380 & .457 & $-.165^{\star \star *}$ & .232 \\
\hline \multirow{2}{*}{$\begin{array}{l}\text { Product } \\
\text { Involvement }\end{array}$} & High & 1 & .405 & 1 & .341 \\
\hline & Low & $-.330^{*}$ & .176 & $-.238^{* * *}$ & .107 \\
\hline \multirow[t]{2}{*}{ Product Value } & Hedonic & 1 & .658 & 1 & .307 \\
\hline & Utilitarian & $-.315^{* * *}$ & .241 & $-.189^{* * *}$ & .107 \\
\hline \multirow{3}{*}{$\begin{array}{l}\text { Type of Social } \\
\text { Media }\end{array}$} & Blog & 1 & .206 & - & - \\
\hline & Facebook & -.007 & .199 & - & - \\
\hline & Twitter & $.309^{\star * *}$ & .477 & - & \\
\hline \multirow{2}{*}{$\begin{array}{l}\text { Study } \\
\text { Characteristics }\end{array}$} & \multirow{2}{*}{ Level } & \multicolumn{2}{|c|}{ Satisfaction-CE } & \multicolumn{2}{|c|}{$\begin{array}{c}\text { Firm } \\
\text { Performance-CE }\end{array}$} \\
\hline & & $b$ & $r$ & $B$ & $r$ \\
\hline \multirow[t]{2}{*}{ Sample Size } & Large & 1 & .201 & 1 & .361 \\
\hline & Small & $-.451^{\star * *}$ & .521 & -.018 & .355 \\
\hline \multirow[t]{2}{*}{ Study Setting } & Experiments & 1 & .432 & 1 & .126 \\
\hline & Surveys & .083 & .468 & $-.189^{*}$ & .321 \\
\hline \multirow[t]{2}{*}{ Publication Type } & Published & 1 & .522 & 1 & .331 \\
\hline & Unpublished & $-.417^{\star \star *}$ & .242 & $-.127^{* * *}$ & .269 \\
\hline
\end{tabular}

Notes: (b) slope coefficient, (r) correlation coefficient, and ( $p$-value) level of significance.

"-" Not available data. ${ }^{* * *} p<.001,{ }^{* *} p<.01,{ }^{*} p<.05$ 
Table 5 - Summary of Customer Engagement Findings

\section{Practical} Implications

1. Customer engagement (CE) is Trust should play a prominent role in any theory of CE. Trust plays an important role in $\mathrm{CE}$ formation both directly and indirectly through satisfaction. engagement and a significant but smaller indirect effect.

2. Positive emotions are not driven by Positive emotions play a role in CE trust and commitment, but have a direct effect on $\mathrm{CE}$ (no indirect formation that is relatively independent of other factors.

Firms need to invest in making sure that touchpoints are characterized by pleasant experiences as much as possible.

3. Satisfaction is a stronger predictor of Suggests the need for more research customer engagement in high (vs. low) convenience. on the role of convenience in $\mathrm{CE}$ formation.

Investments in customer satisfaction programs may be particularly beneficial for convenience consumption settings.

4. B2B (vs. B2C) firms boost $\quad$ Satisfaction and CE more closely $\quad$ B2C firms need to rely on factors other satisfaction to CE path. associated in B2B contexts. than satisfaction to build CE.

5. Twitter appears twice as likely as Suggests a need to better understand other social media platforms (e.g., Facebook) to improve customer Twitter's relatively beneficial characteristics as CE tool.

Firms should consider investing more in an informational activity like Twitter to build $\mathrm{CE}$ relative to other platforms such as Facebook and blogs. and positive emotions.

6. CE has substantial value for We demonstrate the different companies, directly impacting firm performance, behavioral intention, and word-of-mouth. Behavioral intentions mediate $\mathrm{CE}$ effects on firm performance.

7. Word-of-mouth does not improve While CE motivates WOM, WOM does firm performance nor mediate CE effects on firm performance.

8. Low (vs. high) convenience and manufacturing (vs. services) exhibit stronger CE effects on satisfaction and firm performance.

9. High product involvement boosts CE More research is needed to clarify the effects on firm performance, compared to low involvement.

10. Hedonic consumption yields nearly Hedonic value facilitates the three times stronger CE-firm performance effects vis-à-vis utilitarian consumption. mechanisms through which $\mathrm{CE}$, directly and indirectly, impacts firm performance. Conative activities are important in leveraging CE into performance, but not all of CE's positive benefits are mediated. not mediate its effects on performance.

Suggests avenues for further research as CE for brands associated with frequently purchased goods may be easier to leverage. distinctiveness between involvement and $\mathrm{CE}$.

In general, CE is beneficial to firm performance so that in general, investments in CE are supported.

Firms should pay attention more to customer behaviors other than WOM.

Firms associated with convenience should be particularly active in CE investments.

Firms should be particularly attentive to find ways to keep customers involved. leveraging of $\mathrm{CE}$ into performance more than does utilitarian value.
For firms that set $\mathrm{CE}$ as a priority, actions that increase hedonic value are particularly productive. 


\section{CUSTOMER ENGAGEMENT DEFINITIONS AND MEASUREMENTS}

\begin{tabular}{|c|c|c|c|}
\hline $\begin{array}{c}\text { Context / } \\
\text { Perspective }\end{array}$ & Authors & Definitions & Number of Items and Dimensions \\
\hline $\begin{array}{l}\text { Community } \\
\text { engagement } \\
\text { (Intrinsic } \\
\text { Motivation) }\end{array}$ & $\begin{array}{l}\text { Algesheimer } \\
\text { et al. (2005) }\end{array}$ & $\begin{array}{l}\text { Consumer's intrinsic motivation to interact } \\
\text { and cooperate with community members" } \\
\text { - p. } 21\end{array}$ & $\begin{array}{l}4 \text { items for } 1 \text { dimension: Community engagement } \\
\text { ( } a=.90) \text {. } \\
\text { Example: I am very attached to the community. }\end{array}$ \\
\hline $\begin{array}{l}\text { Online brand } \\
\text { community } \\
\text { engagement } \\
\text { (Intrinsic } \\
\text { Motivation) }\end{array}$ & $\begin{array}{l}\text { Baldus et al. } \\
(2015)\end{array}$ & $\begin{array}{l}\text { The compelling, intrinsic motivations to } \\
\text { continue interacting with an online brand } \\
\text { community" - p. } 979\end{array}$ & $\begin{array}{l}42 \text { items for } 10 \text { dimensions: Brand influence } \\
\text { ( } \alpha=.84) \text {, brand passion ( } \alpha=.88) \text {, connecting ( } \alpha=.82) \text {, } \\
\text { helping ( } \alpha=.84) \text {, like-minded discussion }(\alpha=.85) \text {, } \\
\text { rewards (hedonic) ( } \alpha=.87) \text {, rewards (utilitarian) } \\
\text { ( } \alpha=.78) \text {, seeking assistance ( } \alpha=.89) \text {, self- } \\
\text { expression ( } \alpha=.85) \text {, up-to-date information ( } \alpha=.84) \\
\text { and validation ( } \alpha=.85) \text {. } \\
\text { Example: I participate in this brand community } \\
\text { because I care about the brand (brand passion). }\end{array}$ \\
\hline $\begin{array}{l}\text { Brand } \\
\text { engagement } \\
\text { (Psychological } \\
\text { state of mind) }\end{array}$ & $\begin{array}{l}\text { Sprott et al. } \\
(2009)\end{array}$ & $\begin{array}{l}\text { Refers to the tendencies to include } \\
\text { important brands as part of their self- } \\
\text { concept - p. } 92\end{array}$ & $\begin{array}{l}8 \text { items for } 1 \text { dimension: Brand engagement in } \\
\text { self-concept ( } \alpha=.94) \text {. } \\
\text { Example: I have a special bond with the brands that } \\
\text { I like. }\end{array}$ \\
\hline $\begin{array}{l}\text { Online } \\
\text { engagement } \\
\text { (Psychological } \\
\text { state of mind) }\end{array}$ & $\begin{array}{l}\text { Paruthi and } \\
\text { Kaur (2017) }\end{array}$ & $\begin{array}{l}\text { Psychological state of mind as well as an } \\
\text { internal emotion of the consumer - p. } 128\end{array}$ & $\begin{array}{l}16 \text { items for } 4 \text { dimensions: Conscious attention } \\
(\alpha=.85) \text {, affection }(\alpha=.85) \text {, enthused participation } \\
\text { ( } \alpha=.85) \text { and social connection ( } \alpha=.81) \text {. } \\
\text { Example: Engaging with } X \text { makes me feel happy } \\
\text { (affection). }\end{array}$ \\
\hline $\begin{array}{l}\text { Online } \\
\text { engagement } \\
\text { (Activity) }\end{array}$ & $\begin{array}{l}\text { Calder et al. } \\
(2009)\end{array}$ & $\begin{array}{l}\text { "A collection of experiences" (consumer's } \\
\text { beliefs about how a site fits into his/her } \\
\text { life) - p. } 322\end{array}$ & $\begin{array}{l}32 \text { items for } 8 \text { dimensions: Stimulation and } \\
\text { inspiration }(\alpha=.88) \text {, social facilitation }(\alpha=.88) \text {, } \\
\text { temporal }(\alpha=.90) \text {, self-esteem and civic mindedness } \\
\text { ( } \alpha=.91) \text {, intrinsic enjoyment }(\alpha=.87) \text {, utilitarian } \\
\text { ( } \alpha=.88) \text {, participation and socializing }(\alpha=.88) \text {, and } \\
\text { community ( } \alpha=.88) \text {. } \\
\text { Example: Engaging in... it's a treat for me } \\
\text { (enjoyment). }\end{array}$ \\
\hline $\begin{array}{l}\text { Brand } \\
\text { engagement in } \\
\text { social media } \\
\text { (Activity) }\end{array}$ & $\begin{array}{l}\text { Hollebeek et } \\
\text { al. }(2014)\end{array}$ & $\begin{array}{l}\text { "A consumer's positively valenced } \\
\text { cognitive, emotional and behavioral } \\
\text { brand-related activity during, or related to, } \\
\text { specific consumer/brand interactions." - } \\
\text { p. } 154\end{array}$ & $\begin{array}{l}10 \text { items for } 3 \text { dimensions: Affection }(\alpha=.83) \text {, } \\
\text { cognitive processing }(\alpha=.75) \text { and activation }(\alpha=.77) \text {. } \\
\text { Example: Using [brand] stimulates my interest to } \\
\text { learn more about (cognitive processing). }\end{array}$ \\
\hline $\begin{array}{l}\text { Brand } \\
\text { engagement in } \\
\text { social media } \\
\text { (Activity) }\end{array}$ & $\begin{array}{l}\text { Obilo et al. } \\
(2020)\end{array}$ & $\begin{array}{l}\text { "Consumers' positive and negative } \\
\text { behavioral interactions with a brand and } \\
\text { all its constituent elements, beyond } \\
\text { simple transactions, that result from their } \\
\text { interest in and commitment to the brand" } \\
\text { (p. 6) }\end{array}$ & $\begin{array}{l}21 \text { items for } 4 \text { dimensions: Content engagement } \\
\text { ( } \alpha=.94), \text { Advocacy ( } \alpha=.83) \text {, Negative engagement } \\
(\alpha=.76) \text {, and Co-creation activities ( } \alpha=.85) \text {. }\end{array}$ \\
\hline $\begin{array}{l}\text { Blog engagement } \\
\text { (Activity) }\end{array}$ & $\begin{array}{l}\text { Hopp and } \\
\text { Gallicano } \\
(2016)\end{array}$ & $\begin{array}{l}\text { "Includes passive message consumption, } \\
\text { as well as intentions to give online } \\
\text { recommendations, depending on the } \\
\text { engagement level" - p. } 129\end{array}$ & $\begin{array}{l}12 \text { items for } 3 \text { dimensions: Presence }(\alpha=.81) \text {, } \\
\text { utility ( } \alpha=.86) \text { and virality }(\alpha=.84) \text {. } \\
\text { Example: How likely are you to recommend the } \\
\text { blog to someone? (virality). }\end{array}$ \\
\hline $\begin{array}{l}\text { Contribution } \\
\text { to firms }\end{array}$ & $\begin{array}{l}\text { Kumar et al. } \\
\text { (2019) } \\
\text { Pansari and } \\
\text { Kumar (2017) }\end{array}$ & $\begin{array}{l}\text { "Customers become engaged with the } \\
\text { firm when a relationship based on trust } \\
\text { and commitment is satisfying and has } \\
\text { emotional bonding" - p. } 308\end{array}$ & Theoretical \\
\hline
\end{tabular}




\section{WEB APPENDIX PRIMARY STUDIES INCLUDED IN THE META-ANALYSIS}

\begin{tabular}{|c|c|c|c|c|}
\hline Number & Title & Authors & Year & Source \\
\hline 1 & $\begin{array}{l}\text { Building the dream online: Does participation in } \\
\text { luxury brand's social media affect brand } \\
\text { experience, brand affect, brand trust, and } \\
\text { brand loyalty? }\end{array}$ & Parikka, A. & 2015 & Dissertation \\
\hline 2 & $\begin{array}{l}\text { Factors Influencing Customer Engagement in } \\
\text { Mobile Applications }\end{array}$ & $\begin{array}{l}\text { Dovaliene, A.; } \\
\text { Piligrimiene, Z.; } \\
\text { Masiulyte, A. }\end{array}$ & 2016 & Working Paper \\
\hline 3 & $\begin{array}{l}\text { Consumer brand engagement and its social } \\
\text { side on brand-hosted social media: how do } \\
\text { they contribute to brand loyalty? }\end{array}$ & $\begin{array}{l}\text { Helme-Guizon, A.; } \\
\text { Magnoni, F. }\end{array}$ & 2019 & $\begin{array}{l}\text { Journal of Marketing } \\
\text { Management }\end{array}$ \\
\hline 4 & $\begin{array}{l}\text { Influence of e-WOM engagement on consumer } \\
\text { purchase intention in social commerce }\end{array}$ & $\begin{array}{l}\text { Yusuf, A. S.; Hussin, A. } \\
\text { R. C.; Busalim, A. }\end{array}$ & 2018 & Journal of Service Marketing \\
\hline 5 & $\begin{array}{l}\text { Consumer branded\# hashtag engagement: can } \\
\text { creativity in TV advertising influence hashtag } \\
\text { engagement? }\end{array}$ & $\begin{array}{l}\text { Stathopoulou, A.; Borel, } \\
\text { L.; Christodoulides, G.; } \\
\text { West, D. }\end{array}$ & 2017 & Psychology \& Marketing \\
\hline 6 & \begin{tabular}{|l|} 
The Impact of Social Engagement on \\
Customer Profitability-Insights from a Direct \\
Banking Institutions Online Customer \\
\end{tabular} & $\begin{array}{l}\text { Felgenhauer, A.; Klier, } \\
\text { J.; Klier, M.; Lindner, G.. }\end{array}$ & 2017 & Working Paper \\
\hline 7 & $\begin{array}{l}\text { From active participation to engagement in } \\
\text { online communities: Analysing the mediating } \\
\text { role of trust and commitment }\end{array}$ & Vohra, A.; Bhardwaj, N. & 2017 & $\begin{array}{l}\text { Journal of Marketing } \\
\text { Communications }\end{array}$ \\
\hline 8 & $\begin{array}{l}\text { The role of live streaming in building consumer } \\
\text { trust and engagement with social commerce } \\
\text { sellers }\end{array}$ & $\begin{array}{l}\text { Wongkitrungrueng, A.; } \\
\text { Assarutb, N. }\end{array}$ & 2018 & Journal of Business Research \\
\hline 9 & $\begin{array}{l}\text { Mobile Application Driven Consumer } \\
\text { Engagement }\end{array}$ & $\begin{array}{l}\text { Tarute, A.; Nikou, S.; } \\
\text { Gatautis, R. }\end{array}$ & 2017 & Telematics and Informatics \\
\hline 10 & $\begin{array}{l}\text { Corporate Facebook and Customer Brand } \\
\text { Engagement in Kuwait }\end{array}$ & $\begin{array}{l}\text { Bagnied, M.; Speece, } \\
\text { M.; Pongpaew, W.. } \\
\end{array}$ & 2016 & Working Paper \\
\hline 11 & $\begin{array}{l}\text { Influences of customer participation and } \\
\text { customer brand engagement on brand loyalty }\end{array}$ & Solem, B. & 2016 & Journal of Consumer Marketing \\
\hline 12 & $\begin{array}{l}\text { An Experimental Study of the Relationship } \\
\text { between Online Engagement and Advertising } \\
\text { Effectiveness }\end{array}$ & $\begin{array}{l}\text { Calder, B. J.; Malthouse, } \\
\text { E. C.; Schaedel, U. }\end{array}$ & 2009 & Journal of Interactive Marketing \\
\hline 13 & $\begin{array}{l}\text { The impact of external social and internal } \\
\text { personal forces on consumers' brand } \\
\text { community engagement on Facebook }\end{array}$ & $\begin{array}{l}\text { Simon, C.; Brexendorf, } \\
\text { T.; Fassnacht, M. }\end{array}$ & 2016 & $\begin{array}{l}\text { Journal of Product \& Brand } \\
\text { Management }\end{array}$ \\
\hline 14 & $\begin{array}{l}\text { Engaging consumers in esthetic offerings: } \\
\text { conceptualizing and developing a measure for } \\
\text { arts engagement. }\end{array}$ & Kemp, E. & 2015 & \begin{tabular}{|l} 
International Journal of \\
Nonprofit and Voluntary Sector \\
Marketing
\end{tabular} \\
\hline 15 & $\begin{array}{l}\text { Engaging Customers during a website visit: A } \\
\text { model of website customer engagement }\end{array}$ & $\begin{array}{l}\text { Demangeot, C.; } \\
\text { Broderick, A. J. }\end{array}$ & 2016 & $\begin{array}{l}\text { International Journal of Retail \& } \\
\text { Distribution Management }\end{array}$ \\
\hline 16 & $\begin{array}{l}\text { Antecedents and consequences of customer } \\
\text { engagement in online brand communities }\end{array}$ & $\begin{array}{l}\text { Chan, T. K. H.; Zheng, } \\
\text { X.; Cheung, C. M. K.; } \\
\text { Lee, M. K. O.; Lee, Z. W. } \\
\text { Y. }\end{array}$ & 2014 & Journal of Marketing Analytics \\
\hline 17 & $\begin{array}{l}\text { How experience-driven community } \\
\text { identification generates trust and engagement }\end{array}$ & $\begin{array}{l}\text { Hsu, C-P.; Chiang, Y-F.; } \\
\text { Huang, H-C. }\end{array}$ & 2012 & Online Information Review \\
\hline
\end{tabular}




\begin{tabular}{|c|c|c|c|c|}
\hline Number & Title & Authors & Year & Source \\
\hline 18 & $\begin{array}{l}\text { Understanding Cosmopolitan Consumers' } \\
\text { Repeated Purchasing In The E-marketplace: } \\
\text { Contribution From A Brand Orientation }\end{array}$ & $\begin{array}{l}\text { Osakwe, C.; Boateng, } \\
\text { H.; Popa, S.; } \\
\text { Chovancová, M.; Soto- } \\
\text { Acosta, P. }\end{array}$ & 2016 & Marketing and Trade \\
\hline 19 & $\begin{array}{l}\text { Social media engagement in a dedicated } \\
\text { Facebook channel_an analysis of relationships } \\
\text { to emotional attachment, self-brand connection } \\
\text { and brand commitment } \\
\end{array}$ & Hechelmann, C. & 2012 & Dissertation \\
\hline 20 & $\begin{array}{l}\text { Promoting sales of online games through } \\
\text { customer engagement }\end{array}$ & $\begin{array}{l}\text { Cheung, C. M. K.; A, } \\
\text { Shen, X.; Lee, Z. W. Y.; } \\
\text { Chan, T. K. H. }\end{array}$ & 2015 & $\begin{array}{l}\text { Electronic Commerce } \\
\text { Research and Applications }\end{array}$ \\
\hline 21 & $\begin{array}{l}\text { Determinants of consumer engagement in } \\
\text { electronic word-of-mouth (eWOM) in social } \\
\text { networking sites }\end{array}$ & Chu, S-C. & 2011 & $\begin{array}{l}\text { International Journal of } \\
\text { Advertising }\end{array}$ \\
\hline 22 & $\begin{array}{l}\text { Firms' Social Media Efforts, Consumer } \\
\text { Behavior, and Firm Performance: Evidence } \\
\text { from Facebook Firms' Social Media Efforts, } \\
\text { Consumer Behavior, and Firm Performance_ } \\
\text { Evidence from Facebook }\end{array}$ & $\begin{array}{l}\text { Chung, S.; Animesh, A.; } \\
\text { Han, K.; Pinsonneault, A. }\end{array}$ & 2014 & Working Paper \\
\hline 23 & $\begin{array}{l}\text { Antecedents of consumer brand engagement } \\
\text { and brand loyalty }\end{array}$ & $\begin{array}{l}\text { Leckie, C.; Nyadzayo, M. } \\
\text { W.; Johnson, L. W. }\end{array}$ & 2016 & $\begin{array}{l}\text { Journal of Marketing } \\
\text { Management }\end{array}$ \\
\hline 24 & $\begin{array}{l}\text { Social media-inzet door KLM: De relatie met } \\
\text { online enfagement en bedrijreputatie }\end{array}$ & $\begin{array}{l}\text { Dijkmans, C.; Kerkhof, P; } \\
\text { Beukeboom, C. J. }\end{array}$ & 2015 & Vrijetijdsstudies \\
\hline 25 & $\begin{array}{l}\text { A stage to engage: Social media use and } \\
\text { corporate reputation }\end{array}$ & $\begin{array}{l}\text { Dijkmans, C; Kerkhof, P; } \\
\text { Beukeboom, C. J. }\end{array}$ & 2015 & Tourism Management \\
\hline 26 & $\begin{array}{l}\text { The role of self-construal in consumers' } \\
\text { electronic word of mouth (eWOM) in social } \\
\text { networking sites: A social cognitive approach. }\end{array}$ & $\begin{array}{l}\text { Lee, D.;Kim, H. S.; Kim, } \\
\text { J. K. }\end{array}$ & 2012 & Computers in Human Behavior \\
\hline 27 & $\begin{array}{l}\text { Sports sponsorship as a channel for brand } \\
\text { engagement on social media }\end{array}$ & Karppinen, E. & 2016 & Dissertation \\
\hline 28 & $\begin{array}{l}\text { Engaging consumers and building relationships } \\
\text { in social media: How social relatedness } \\
\text { influences intrinsic vs. extrinsic consumer } \\
\text { motivation }\end{array}$ & Kim, E.;, Drumwright, M. & 2016 & Computers in Human Behavior \\
\hline 29 & $\begin{array}{l}\text { Antecedentes e consequentes do luxury brand } \\
\text { engagement no Facebook: Aproximação ao } \\
\text { Modelo de Equaçoes Estruturais. }\end{array}$ & De Pinho, E. P. & 2015 & Dissertation \\
\hline 30 & $\begin{array}{l}\text { Beyond the Usefulness of Branded } \\
\text { Applications_Insights from Consumer-Brand } \\
\text { Engagement and Self-construal Perspective }\end{array}$ & Fang, Y-H. & 2017 & Psychology \& Marketing \\
\hline 31 & $\begin{array}{l}\text { The influence of cultural blogs on their readers' } \\
\text { cultural product choices }\end{array}$ & Magno, F. & 2017 & \begin{tabular}{|l|} 
International Journal of \\
Information Management
\end{tabular} \\
\hline 32 & $\begin{array}{l}\text { Does brand-consumer social sharing matter? A } \\
\text { relational framework of customer engagement } \\
\text { to brand-hosted social media }\end{array}$ & Simon, F.; Tossan, V. & 2018 & Journal of Business Research \\
\hline 33 & $\begin{array}{l}\text { The impact of referral rewards systems for } \\
\text { online content creation }\end{array}$ & $Y u, G$. & 2016 & Dissertation \\
\hline
\end{tabular}




\begin{tabular}{|c|c|c|c|c|}
\hline Number & Title & Authors & Year & Source \\
\hline 34 & $\begin{array}{l}\text { How trust moderates social media engagement } \\
\text { and brand equity }\end{array}$ & Chahal, H.; Verma, A. & 2017 & $\begin{array}{l}\text { Journal of Research in } \\
\text { Interactive Marketing }\end{array}$ \\
\hline 35 & Motivational Drivers of Behavioral & Hepola, J. & 2015 & Dissertation \\
\hline 36 & $\begin{array}{l}\text { The role of customer brand engagement and } \\
\text { brand experience in online banking }\end{array}$ & $\begin{array}{l}\text { Khan, I.; Rahman, Z.; } \\
\text { Fatma, M. }\end{array}$ & 2016 & $\begin{array}{l}\text { International Journal of Bank } \\
\text { Marketing }\end{array}$ \\
\hline 37 & $\begin{array}{l}\text { A Brand Like a Friend - The Influence of } \\
\text { Customer Engagement with Social Media } \\
\text { Brand Pages on Brand Relationships and } \\
\text { Loyalty Intentions }\end{array}$ & Jahn, B.; Kunz, W. H. & 2014 & SSRN Electronic Journal \\
\hline 38 & $\begin{array}{l}\text { How to transform consumers into fans of your } \\
\text { brand }\end{array}$ & Jahn, B.; Kunz, W. H. & 2012 & $\begin{array}{l}\text { Journal of Service } \\
\text { Management }\end{array}$ \\
\hline 39 & $\begin{array}{l}\text { Online brand community: through the eyes of } \\
\text { Self-Determination Theory }\end{array}$ & Kelley, J; Alden, D. L. & 2016 & Internet Research \\
\hline 40 & $\begin{array}{l}\text { Linking customer engagement to trust and } \\
\text { word-of-mouth on Facebook brand } \\
\text { communities: An empirical study }\end{array}$ & $\begin{array}{l}\text { Islam, J. U. I.; Rahman, } \\
\text { Z. }\end{array}$ & 2016 & Journal of Internet Commerce \\
\hline 41 & $\begin{array}{l}\text { Personality factors as predictors of online } \\
\text { consumer engagement: an empirical } \\
\text { investigation }\end{array}$ & $\begin{array}{l}\text { Islam, J. U. I.; Rahman, } \\
\text { Z.; Hollebeek, L. D. }\end{array}$ & 2017 & $\begin{array}{l}\text { Marketing Intelligence and } \\
\text { Planning }\end{array}$ \\
\hline 42 & $\begin{array}{l}\text { The effect of sensory brand experience and } \\
\text { involvement on brand equity directly and } \\
\text { indirectly through consumer brand } \\
\text { engagement. }\end{array}$ & $\begin{array}{l}\text { Hepola, J.; Karjaluoto, } \\
\text { H.; Hintikka, A. }\end{array}$ & 2017 & $\begin{array}{l}\text { Journal of Product \& Brand } \\
\text { Management }\end{array}$ \\
\hline 43 & $\begin{array}{l}\text { How brand post content contributes to user's } \\
\text { Facebook brand-page engagement. }\end{array}$ & $\begin{array}{l}\text { Gutiérrez-Cillán, J.; } \\
\text { Camarero-Izquierdo, C.; } \\
\text { José-Cabezudo, R. S. }\end{array}$ & 2017 & Business Research Quartely \\
\hline 44 & $\begin{array}{l}\text { Customer engagement in a Facebook brand } \\
\text { community }\end{array}$ & $\begin{array}{l}\text { Gummerus, J.; Liljander, } \\
\text { V.; Weman, E.; } \\
\text { Pihlström, M. }\end{array}$ & 2012 & Management Research Review \\
\hline 45 & $\begin{array}{l}\text { Are Facebook Brand Community Members } \\
\text { Really Loyal to the Brand }\end{array}$ & $\begin{array}{l}\text { Karjaluoto, H.; } \\
\text { Munnukka, J.; Tikkanen, } \\
\text { A. }\end{array}$ & 2014 & Working Paper \\
\hline 46 & $\begin{array}{l}\text { Online brand community: through the eyes of } \\
\text { Self-Determination Theory }\end{array}$ & Kelley, J. B.; Alden, D. L. & 2016 & Internet Research \\
\hline 47 & $\begin{array}{l}\text { Enhancing Customer Relationships with Retail } \\
\text { Service Brands: }\end{array}$ & $\begin{array}{l}\text { So, K. K. F.; King, C.; } \\
\text { Sparks, B. A.; Wang, Y. }\end{array}$ & 2016 & $\begin{array}{l}\text { Journal of Service } \\
\text { Management }\end{array}$ \\
\hline 48 & $\begin{array}{l}\text { Engaging customers through online } \\
\text { participation in social networking sites }\end{array}$ & Kujur, F.; Singh, S. & 2017 & $\begin{array}{l}\text { Asia Pacific Management } \\
\text { Review }\end{array}$ \\
\hline 49 & $\begin{array}{l}\text { The Effects of Social Media Based Brand } \\
\text { Communities on brand community markers, } \\
\text { value creation practices, brand trust and brand } \\
\text { loyalty }\end{array}$ & $\begin{array}{l}\text { Laroche, M.; Habibi, M. } \\
\text { R.; Richard, M-O.; } \\
\text { Sankaranarayanan, R. }\end{array}$ & 2012 & Computers in Human Behavior \\
\hline 50 & $\begin{array}{l}\text { Social media engagement: a model of } \\
\text { antecedents and relational outcomes }\end{array}$ & Dessart, L. & 2017 & $\begin{array}{l}\text { Journal of Marketing } \\
\text { Management }\end{array}$ \\
\hline 51 & $\begin{array}{l}\text { A model of value-creating practices, trusting } \\
\text { beliefs, and online tourist community } \\
\text { behaviors: Risk aversion as a moderating } \\
\text { variable }\end{array}$ & Lee, K.; Hyun, S. & 2016 & $\begin{array}{l}\text { International Journal of } \\
\text { Contemporary Hospitality } \\
\text { Management }\end{array}$ \\
\hline
\end{tabular}




\begin{tabular}{|c|c|c|c|c|}
\hline Number & Title & Authors & Year & Source \\
\hline 52 & $\begin{array}{l}\text { Exploring the impact of rewarded social media } \\
\text { engagement in loyalty programs }\end{array}$ & $\begin{array}{l}\text { Rehnen, L-M.; Bartsch, } \\
\text { S.; Kull, M.; Meyer, A. }\end{array}$ & 2017 & $\begin{array}{l}\text { Journal of Service } \\
\text { Management }\end{array}$ \\
\hline 53 & $\begin{array}{l}\text { Factors of continually using branded mobile } \\
\text { apps: the central hole of app engagement }\end{array}$ & Wu, L. & 2015 & $\begin{array}{l}\text { Intertional Journal Internet } \\
\text { Marketing and Advertising }\end{array}$ \\
\hline 54 & $\begin{array}{l}\text { Engagement in online communities: } \\
\text { implications for consumer price perceptions }\end{array}$ & $\begin{array}{l}\text { Nguyen,L. T. V.; } \\
\text { Conduit, J.; Lu, V. N.; \& } \\
\text { Hill, S. R. }\end{array}$ & 2015 & Journal of Strategic Marketing \\
\hline 55 & $\begin{array}{l}\text { The effects of value co-creation practices on } \\
\text { building harmonious brand community and } \\
\text { achieving brand loyalty on social media in } \\
\text { China. }\end{array}$ & $\begin{array}{l}\text { Luo, N.; Zhang, M.; Liu, } \\
\text { W. }\end{array}$ & 2015 & Computers in Human Behavior \\
\hline 56 & $\begin{array}{l}\text { Understanding relationship benefits from } \\
\text { harmonious brand community on social media }\end{array}$ & Zhang, M.; Luo, N. & 2016 & Internet Research \\
\hline 57 & $\begin{array}{l}\text { An integrated model of social media brand } \\
\text { engagement }\end{array}$ & $\begin{array}{l}\text { Gómez, M.; Lopez, C.; } \\
\text { Molina, A. }\end{array}$ & 2019 & Computers in Human Behavior \\
\hline 58 & $\begin{array}{l}\text { Antecedents of brand love in online network- } \\
\text { based communities. A social identity } \\
\text { perspective }\end{array}$ & $\begin{array}{l}\text { Vernuccio, M.; Pagani, } \\
\text { M.; Barbarossa, C.; } \\
\text { Pastore, A. }\end{array}$ & 2015 & $\begin{array}{l}\text { Journal of Product \& Brand } \\
\text { Management }\end{array}$ \\
\hline 59 & $\begin{array}{l}\text { Engagement-Based Loyalty: The Effects of } \\
\text { Social Media Engagement on Customer } \\
\text { Loyalty in the Travel Industry }\end{array}$ & $\begin{array}{l}\text { van Asperen, M.; de } \\
\text { Rooij, P.; Dijkmans, C. }\end{array}$ & 2017 & $\begin{array}{l}\text { International Journal of } \\
\text { Hospitability and Tourism } \\
\text { Administration } \\
\end{array}$ \\
\hline 60 & $\begin{array}{l}\text { Fan community identification: An empirical } \\
\text { examination of its outcomes in Japanese } \\
\text { professional sport }\end{array}$ & $\begin{array}{l}\text { Yoshida, M.; Gordon, B. } \\
\text { S.; Heere, B.; James, J. } \\
\text { D. }\end{array}$ & 2015 & Sport Marketing Quarterly \\
\hline 61 & $\begin{array}{l}\text { Consumer engagement on social media_ } \\
\text { analysis of scales and its multiple role in a } \\
\text { nomological network }\end{array}$ & Ferreira, M. & 2017 & Dissertation \\
\hline 62 & $\begin{array}{l}\text { Infuencing consumer engagement in online } \\
\text { customer: The role of interactivity }\end{array}$ & Mpinganjira, M. & 2016 & $\begin{array}{l}\text { Independent Research Journal } \\
\text { in The Management Sciences }\end{array}$ \\
\hline 63 & $\begin{array}{l}\text { A model of brand engagement in online brand } \\
\text { communities: Co-creating value for the brand } \\
\text { and the community }\end{array}$ & Alotaibi, M. H. & 2016 & Dissertation \\
\hline 64 & $\begin{array}{l}\text { The role of personalization, engagement, and } \\
\text { trust in online communities }\end{array}$ & $\begin{array}{l}\text { Kang, M.; Shin, D-H.; } \\
\text { Gong, T. }\end{array}$ & 2016 & $\begin{array}{l}\text { Information Technology \& } \\
\text { People }\end{array}$ \\
\hline 65 & $\begin{array}{l}\text { The Effect of Customer-Brand Engagement on } \\
\text { Customer's Value Co-Creation Through } \\
\text { Mediating Role of Brand Experience }\end{array}$ & Azad, N.; Allahyari, M. & 2017 & $\begin{array}{l}\text { Journal of Fundamental and } \\
\text { Applied Sciences }\end{array}$ \\
\hline 66 & $\begin{array}{l}\text { Investigating the role of online community } \\
\text { engagement and consumer online collective } \\
\text { empowerment for consumer price fairness } \\
\text { perception }\end{array}$ & Nguyen, L. & 2015 & Dissertation \\
\hline 67 & $\begin{array}{l}\text { The influence of switching costs and } \\
\text { satisfaction on loyalty towards smartphone } \\
\text { service providers }\end{array}$ & $\begin{array}{l}\text { Calvo-Porral, C.; } \\
\text { Mangin, J.P. }\end{array}$ & 2015 & $\begin{array}{l}\text { International Journal of Mobile } \\
\text { Communications }\end{array}$ \\
\hline 68 & $\begin{array}{l}\text { Consumer Brand Engagement in Social Media: } \\
\text { Conceptualization, Scale Development \& } \\
\text { Validation }\end{array}$ & $\begin{array}{l}\text { Hollebeek, L. D.; Glynn, } \\
\text { M. S.; Brodie, R. J. }\end{array}$ & 2014 & Journal of Interactive Marketing \\
\hline
\end{tabular}




\begin{tabular}{|c|c|c|c|c|}
\hline Number & Title & Authors & Year & Source \\
\hline 69 & $\begin{array}{l}\text { Experiential Engagement and Active vs. } \\
\text { Passive Behavior in Mobile Location-based } \\
\text { Social Networks: The Moderating Role of } \\
\text { Privacy }\end{array}$ & $\begin{array}{l}\text { Pagani, M.; Malacarne, } \\
\text { G. }\end{array}$ & 2017 & Journal of Interactive Marketing \\
\hline 70 & $\begin{array}{l}\text { Customer engagement with tourism social } \\
\text { media brands }\end{array}$ & $\begin{array}{l}\text { Harrigan, P.; Evers, U.; } \\
\text { Miles, M.; Daly, T. }\end{array}$ & 2017 & Tourism Management \\
\hline 71 & $\begin{array}{l}\text { Does Customer Engagement on Social Media } \\
\text { Matters to Value Co-Creation? }\end{array}$ & Chahal, H.; Verma, A. & 2015 & Working Paper \\
\hline 72 & $\begin{array}{l}\text { Understanding Customer Engagement and } \\
\text { Loyalty: A Case of Mobile Device for Shopping }\end{array}$ & Thakur, R. & 2016 & $\begin{array}{l}\text { Journal of Retailing and } \\
\text { Consumer Services }\end{array}$ \\
\hline 73 & $\begin{array}{l}\text { Online consumer engagement__Understanding } \\
\text { the antecedents and outcomes }\end{array}$ & Reitz, A. R. & 2012 & Dissertation \\
\hline 74 & $\begin{array}{l}\text { The role of social and parasocial relationships } \\
\text { on social networking sites loyalty. }\end{array}$ & Tsiotsou, R. H. & 2015 & Computers in Human Behavior \\
\hline 75 & $\begin{array}{l}\text { The Role of Brand Personality on Brand } \\
\text { Relationships and Tribal Behavior: An } \\
\text { Integrative Model }\end{array}$ & $\begin{array}{l}\text { Tsiotsou, R. H.; } \\
\text { Veloutsou, C. }\end{array}$ & 2011 & Working Paper \\
\hline 76 & $\begin{array}{l}\text { Analyzing the effect of social support and } \\
\text { community factors on customer engagement } \\
\text { and its impact on loyalty behaviors toward } \\
\text { social commerce websites }\end{array}$ & $\begin{array}{l}\text { Molinillo, S.; Anaya- } \\
\text { Sánchez, R.; Liébana- } \\
\text { Cabanillas, F. }\end{array}$ & 2019 & Computers in Human Behavior \\
\hline 77 & $\begin{array}{l}\text { The Impact of Social Media Based Brand } \\
\text { Communities on Brand Community Markers } \\
\text { and Value Creation Practices in an Apple } \\
\text { (iphone) Mobile }\end{array}$ & $\begin{array}{l}\text { Mosavi, S. A.; } \\
\text { Kenarehfard, M. }\end{array}$ & 2014 & $\begin{array}{l}\text { Indian Journal Science } \\
\text { Resource }\end{array}$ \\
\hline 78 & $\begin{array}{l}\text { Luxury-cruise travellers' brand community } \\
\text { perception and its consequences. }\end{array}$ & $\begin{array}{l}\text { Shim, C.; Kang, S.; Kim, } \\
\text { I.; Hyun, S. S. }\end{array}$ & 2015 & Current Issues in Tourism \\
\hline 79 & $\begin{array}{l}\text { Responses to an advergaming campaign on a } \\
\text { mobile social networking site: An initial } \\
\text { research report }\end{array}$ & $\begin{array}{l}\text { Okazaki, S.; Yagüe, M. } \\
\text { J. }\end{array}$ & 2012 & Computers in Human Behavior \\
\hline 80 & $\begin{array}{l}\text { Brand engagement on social media: will firms' } \\
\text { social media efforts influence search engine } \\
\text { advertising effectiveness? }\end{array}$ & $\begin{array}{l}\text { Yang, S.; Lin, S.; } \\
\text { Carlson, J. R.; Ross Jr., } \\
\text { W. T. Jr. }\end{array}$ & 2016 & $\begin{array}{l}\text { Journal of Marketing } \\
\text { Management }\end{array}$ \\
\hline 81 & Consumer Engagement in Online Settings & $\begin{array}{l}\text { Vinerean, S.; Opreana, } \\
\text { A. }\end{array}$ & 2015 & Expert Journal of Marketing \\
\hline 82 & $\begin{array}{l}\text { The Central Role of Engagement in Online } \\
\text { Communities }\end{array}$ & $\begin{array}{l}\text { Ray, S.; Kim, S. S.; } \\
\text { Morris, J. G. }\end{array}$ & 2014 & Information Systems Research \\
\hline 83 & $\begin{array}{l}\text { Online brand engagement: an investigation on } \\
\text { antecedents and outcomes within the social } \\
\text { media environment }\end{array}$ & Gorgus, T. M. C. & 2016 & Dissertation \\
\hline 84 & $\begin{array}{l}\text { How to engage customers in co-creation } \\
\text { customers' motivations for collaborative } \\
\text { innovation }\end{array}$ & $\begin{array}{l}\text { Fernandes, T.; Remelhe, } \\
\text { P. }\end{array}$ & 2016 & Journal of Strategic Marketing \\
\hline 85 & $\begin{array}{l}\text { Benefitting from virtual customer environments: } \\
\text { An empirical study of customer engagement }\end{array}$ & $\begin{array}{l}\text { Verhagen, T.; Swen, E.; } \\
\text { Feldberg, F.; Merikivi, J. }\end{array}$ & 2015 & Computers in Human Behavior \\
\hline 86 & $\begin{array}{l}\text { Customer-brand engagement and Facebook } \\
\text { fan-page 'like' intention }\end{array}$ & $\begin{array}{l}\text { Halaszovich, T. F.; Nel, } \\
\text { J. }\end{array}$ & 2017 & $\begin{array}{l}\text { Journal of Product \& Brand } \\
\text { Management }\end{array}$ \\
\hline 87 & $\begin{array}{l}\text { Development and test of a multidimensional } \\
\text { scale of blog engagement. }\end{array}$ & $\begin{array}{l}\text { Hopp, T.; Gallicano, T. } \\
\text { D. }\end{array}$ & 2016 & $\begin{array}{l}\text { Journal of Public } \\
\text { Relasthionship }\end{array}$ \\
\hline
\end{tabular}




\begin{tabular}{|c|c|c|c|c|}
\hline Number & Title & Authors & Year & Source \\
\hline 88 & $\begin{array}{l}\text { The social aspects of consumption as } \\
\text { predictors of consumer loyalty_ Online vs } \\
\text { offline services }\end{array}$ & Tsiotsou, R. H. & 2016 & $\begin{array}{l}\text { Journal of Service } \\
\text { Management }\end{array}$ \\
\hline 89 & $\begin{array}{l}\text { Measuring consumer brand engagement on } \\
\text { social media with annoyance as a moderator }\end{array}$ & Tanttu, T. & 2017 & Dissertation \\
\hline 90 & $\begin{array}{l}\text { Determinant factors of time spent on } \\
\text { Facebook: brand community engagement and } \\
\text { usage types. }\end{array}$ & Ulusu, Y. & 2010 & Journal of Yasar University \\
\hline 91 & $\begin{array}{l}\text { Brand evaluation, satisfaction and trust as } \\
\text { predictors of brand loyalty: the mediator- } \\
\text { moderator effect of brand relationships }\end{array}$ & Veloutsou, C. & 2015 & Journal of Consumer Marketing \\
\hline 92 & $\begin{array}{l}\text { Understanding factors of disengagement within } \\
\text { a virtual community: an exploratory study. }\end{array}$ & Dutot, V.; Mosconi, E. & 2016 & Journal of Decision Systems \\
\hline 93 & $\begin{array}{l}\text { A dual identification framework of online } \\
\text { multiplayer video games: The case of } \\
\text { massively multiplayer online role playing } \\
\text { games (MMORPGs) }\end{array}$ & $\begin{array}{l}\text { Badrinarayanan, V.; } \\
\text { Sierra, J. J.; Martin, K. } \\
\text { M. }\end{array}$ & 2015 & Journal of Business Research \\
\hline 94 & $\begin{array}{l}\text { Examining the drivers and brand performance } \\
\text { implications of customer engagement with } \\
\text { brands in the social media environment. }\end{array}$ & De Vries, N.; Carlson, J. & 2014 & Journal of Brand Management \\
\hline 95 & $\begin{array}{l}\text { Leveraging marketer-generated appeals in } \\
\text { online brand communities: An individual user- } \\
\text { level analysis }\end{array}$ & $\begin{array}{l}\text { Weiger, W.; Wetzel, H.; } \\
\text { Hammerschmidt, M. }\end{array}$ & 2017 & $\begin{array}{l}\text { Journal of Service } \\
\text { Management }\end{array}$ \\
\hline 96 & $\begin{array}{l}\text { Exploring the Perceptual and Behavioral } \\
\text { Outcomes of Public Engagement on Mobile } \\
\text { Phones and Social Media }\end{array}$ & $\begin{array}{l}\text { Wang, Y.; Ki, E-J.; Kim, } \\
\text { Y. }\end{array}$ & 2017 & $\begin{array}{l}\text { International Journal of } \\
\text { Strategic Communication }\end{array}$ \\
\hline 97 & $\begin{array}{l}\text { Mediating impact of fan-page engagement on } \\
\text { social media connectedness and followers } \\
\text { purchase intention }\end{array}$ & \begin{tabular}{|l|} 
Rahman, Z.; \\
Moghavvemi, S.; \\
Zanuddin, H.; \\
Suberamanian, K.; Nasir, \\
H. N. B. M.
\end{tabular} & 2018 & Online Information Review \\
\hline
\end{tabular}

